\title{
D. Alexandre de Sousa e Holstein e a cultura lusitana numa Roma em ebulição (1790-1803)
}

\author{
D. Alexandre de Sousa e Holstein \\ and the Portuguese culture in a Rome in disarray (1790-1803)
}

\section{Francisco Almeida Dias ${ }^{1}$}

\section{RESUMO}

As conceções neoclássicas, propaladas pela produção teórica de Winckelmann e Mengs, encontraram em Roma, no fim do século XVIII, uma aplicação concreta, no que concerne a formação artística dos jovens portugueses enviados pela Casa Pia de Lisboa, ou vindos com subvenções alternativas, como Sequeira ou Vieira Portuense. A fundação de uma efémera Academia de Belas-Artes teve em D. Alexandre de Sousa e Holstein um protagonista requintado e culto, que viu o seu projeto interrompido por vicissitudes familiares e pela agitação política europeia, pressagiando a invasão da cidade de Pio VI pelas tropas de Berthier em 1798. Será o mesmo diplomata que, na sua segunda enviatura, irá dissolver o estabelecimento, projetado em colaboração com o Intendente-geral Pina Manique e posto em movimento com a preciosa intervenção do crítico de arte, colecionador e bibliófilo Giovanni Gherardo De Rossi. Nessa Urbe que reencontra devastada, irá morrer também, daí a pouco, o próprio D. Alexandre. Provindo de uma família excecional e prosseguidor de uma descendência ilustríssima, tem simbolicamente, na efígie sepulcral, finamente cinzelada pelo inefável Canova, a chave de ouro com que fecha a sua vida - uma vida que espera ainda um merecido estudo de grande fôlego.

Palavras-chave: Prelúdio e epílogo da Repubblica Romana (1798-99), Aplicação das teorias neoclássicas no ensino das artes (Winckelmann e Mengs), D. Alexandre de Sousa e Holstein (1751-1803), Academia Portuguesa de Belas-Artes de Roma (1791-1803), Primeiro período romano de Domingos António de Sequeira (1788-1795).

\section{ABSTRACT}

The neoclassical conceptions, promoted by the theoretical production of Winckelmann and Mengs found a concrete application in Rome at the end of the eighteenth century in the artistic education of the young Portuguese people sent by the Casa Pia of Lisbon or provided with alternative scholarships such as Sequeira or Vieira Portuense. The foundation of an ephemeral Academy of Fine Arts found in D. Alexandre de Sousa e Holstein a refined and educated protagonist who saw his project interrupted by family issues and by the European political turbulence, which prefigured the invasion of the city of Pius VI by the army of Berthier in 1798. It will be the same diplomat who, in his second mission, will dissolve the Academy planned in

1 Instituto Português de Santo António em Roma /Università degli Studi della Tuscia - Dipartimento di studi linguisticoletterari, storico-filosofici e giuridici 


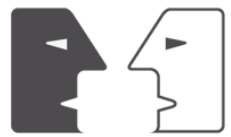

ANTÍTESES

collaboration with the Intendant Pina Manique and established with the precious intervention of the art critic, collector and bibliophile Giovanni Gherardo de Rossi. Returned in a devastated Rome, D. Alexandre will die soon afterwards. Coming from an exceptional family and giving birth to an illustrious progeny, in his sepulchral effigy finely carved by the ineffable Canova he ends symbolically a life that still awaits a deserved extensive study.

Keyword: Prelude and epilogue of the Repubblica Romana (1798-99), Application of neoclassical theories in the teaching of the arts (Winckelmann and Mengs), D. Alexandre de Sousa e Holstein (1751-1803), Portuguese Academy of Fine Arts of Rome (1791-1803), First Roman period of Domingos António de Sequeira (1788-1795)

As qualidades de espírito, ilustração e bondade de alma, haviam tornado D. Alexandre um personagem de distinção invulgar. De boa presença: loiro, corado, de olhos azuis, nos quais se lhe adivinhava a ancestralidade escandinava, alegre e arguto, artista e erudito, sociável e mundano, eralhe familiar a vida dos grandes salões das cortes europeias, onde fazia ouvir o estridor da gargalhada franca com que sublinhava um dito de espírito.(MARTINS, 1942, 380-381)²

\section{Imagem 1. Alexandre de Sousa e Holstein}
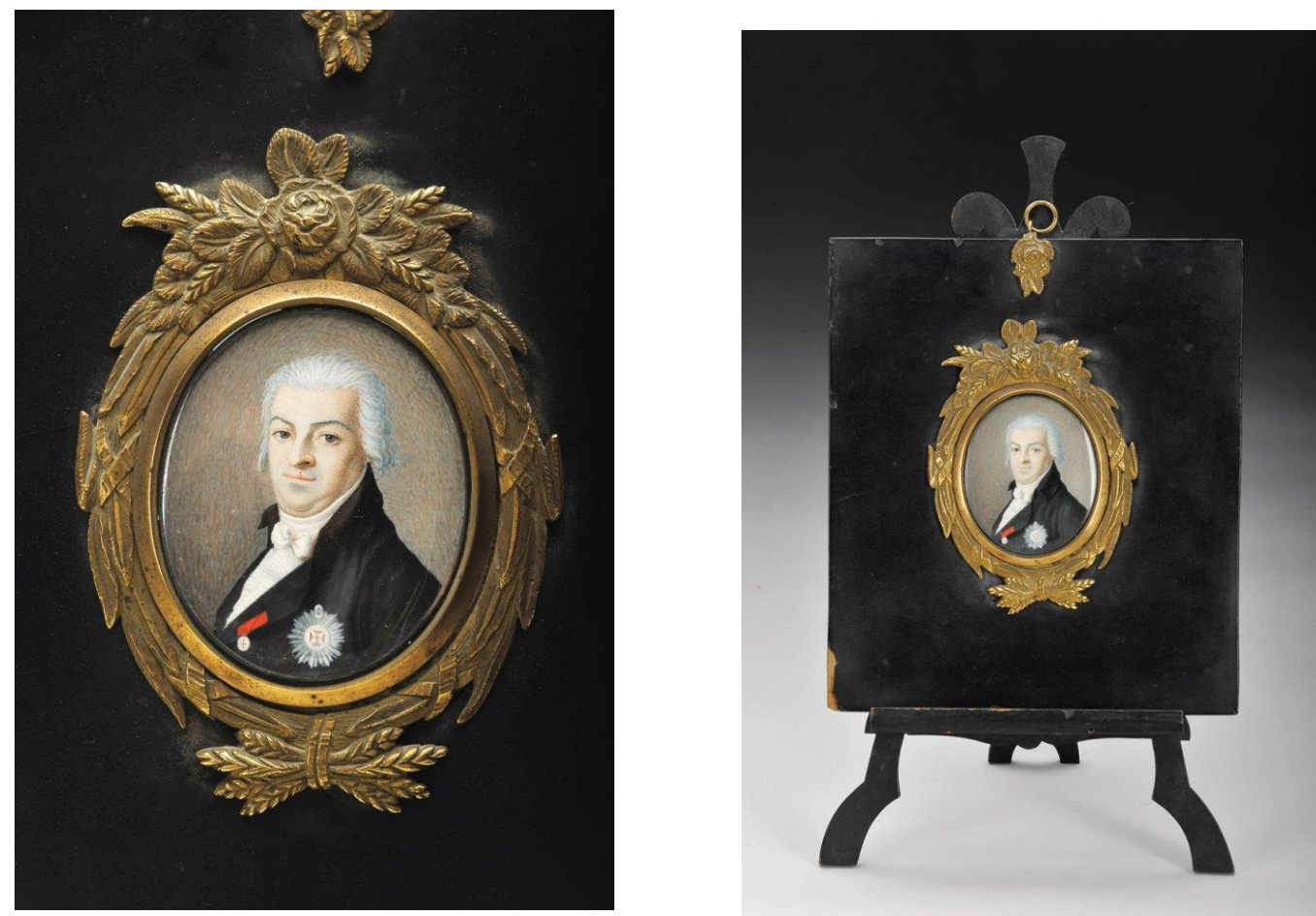

Fonte: Retrato de D. Alexandre de Sousa e Holstein, com a cruz da Ordem de Cristo, de que foi feito cavaleiro em 1785, miniatura sobre marfim, 7x6 cm, vendido a 31 de maio de 2011 no leilão «Antiguidades e Obras de Arte» da leiloeira Cabral Moncada.

\footnotetext{
${ }^{2}$ Neste artigo optou-se por uniformizar a grafia de todos os documentos citados, segundo o atual Acordo Ortográfico da
} Língua Portuguesa. Tal não acontece, porém, com os títulos da bibliografia. 
Para uma resenha biográfica inicial, importa acrescentar que Alexandre Domingos de Sousa e Holstein era filho de D. Manuel de Sousa ${ }^{3}$, membro daquela alta nobreza que não escapou às perseguições perpetradas pelo futuro Marquês de Pombal, tendo vindo a morrer da gangrena causada pelos grilhões do Forte da Junqueira, onde era preso de Estado. Sua mãe era a Princesa Maria Anna Leopoldina von Schleswig-Holstein-Sonderburg-Beck, filha da Condessa Maria Antónia de Sanfré e de Frederico Guilherme, Duque reinante de Holstein, aparentada por esta via com as Casas reais da Inglaterra e da Dinamarca. Apesar de quarto varão, será $\mathrm{D}$. Alexandre chamado à sucessão da Casa dos Sousas de Calhariz por morte do irmão mais velho e ao Morgadio e Condado de Sanfré, no Piemonte, Itália, em sucessão de sua avó materna ${ }^{4}$.

\section{Imagem 2. Maria Anna Leopoldina von Schleswig-Holstein- Sonderburg-Beck representada como deusa Diana}

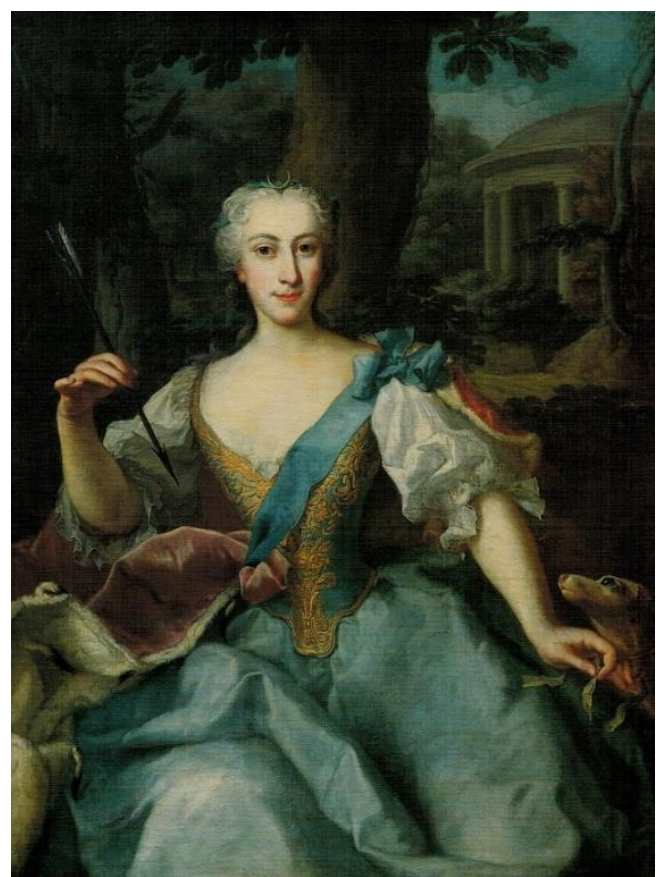

Fonte: quadro atribuído a Anton Raffael Mengs (c.1740), óleo s/ tela, 125x94 cm, col. particular reproduzido em PAIS, 2001, 141.

D. Alexandre nasce em Lisboa, a 4 de dezembro de 1751 e a sua biografia parece "entalada" entre o brilho dos seus sucessores - in primis, o do filho, o primeiro Duque de Palmela - e a

${ }^{3} 7^{\circ}$ Capitão da Guarda Real Alemã, Fidalgo da Casa de D. João V, Alcaide-mor da Sertã e de Ervededo, Senhor dos morgados de Calhariz, Monfalim, Fonte do Anjo e de Santa Maria dos Olivais, Senhor de várias Comendas da Ordem de Cristo, Deputado da Junta dos Três Estados (cf. RIO MAIOR, 1936, 8 ss. e SAMPAYO, 1929).

${ }^{4}$ Era, para além disto, $13^{\circ}$ Morgado do Calhariz, $13^{\circ}$ Morgado de Monfalim, $13^{\circ}$ Morgado de Tavira, $13^{\circ}$ Morgado da Fonte do Anjo, $11^{\circ}$ Morgado de Azeitão, $9^{\circ}$ Morgado dos Anjos, $8^{\circ}$ Morgado de Santarém em sucessão do irmão D. Frederico Guilherme de Sousa. Padroeiro da igreja de São Paio de Eira Vedra, no concelho de Vieira (doação de D. Afonso V a antepassados Sousa de Calhariz), $10^{\circ}$ capitão da Guarda Real Alemã (carta de 17.6.1795), Moço-fidalgo da Casa do rei D. José (alvará de 20.6.1757), Alcaide-mor da Sertã, fazia parte do Conselho de D. Maria I, era Comendador de S. Salvador da Infesta e de Santa Maria de Belmonte, Cavaleiro das Ordens de Cristo e de S. João de Jerusalém, Capitão-tenente de Infantaria Estrangeira do Duque de Ciablese, antes de ser Embaixador em Roma, foi Ministro plenipotenciário nas Cortes de Copenhaga (1786), Berlim (1789) e Conselheiro de Estado (9.7.1796) - cf. extra-texto “Árvore Genealógica da Família Sousa e Holstein - Duques de Palmela" in PAIS, 2001. 
grandeza dos seus antepassados. Recorde-se, por exemplo, a figura do seu tio-bisavô D. Luís de Sousa (1637-1690), Bispo de Lamego e feito Arcebispo de Braga durante a sua estadia como Embaixador de D. Pedro II em Roma, junto das cortes de Clemente X Altieri e Inocêncio XI Odescalchi, de 1675 a 1682. As "suas capacidades linguísticas e dotes poéticos, além das qualidades naturais de um perfeito cortesão, de escrita habilíssima e trato fidalgo" (PAIS, 2001, 15) fizeram-se bem visíveis junto da Cúria papal, onde entrou triunfalmente e constituiu uma magnífica coleção de arte, facto certamente marcante na sensibilidade e formação cultural dos seus descendentes (cf. PAIS, 2001, 17).

Também o primeiro casamento de D. Alexandre, a 27 de junho de 1778, com D. Isabel Juliana Bazeliza de Sousa Coutinho Monteiro Paim ${ }^{5}$ foi um evento notável, ou não se tratasse ela do célebre "bichinho de conta" - como passou à história portuguesa, pela resistência à consumação do matrimónio, mais tarde anulado, imposto pelo Conde de Oeiras com o seu segundo filho, João Francisco. De nobreza antica e rica, era a única filha de D. Vicente de Sousa Coutinho, Ministro de Portugal em Paris em 1790, donde transmitu para Lisboa a evolução dos motes revolucionários franceses (cf. BEIRÃO, 1944, 382-391). Membro de uma família excecional, casado com uma mulher excecional, de quem viriam a descender personalidades excecionais (cf. ZUQUETE, 1960, 99) D. Alexandre parecia destinado à relativa sombra em que tem permanecido.

É, de facto, escassa e escassamente biográfica a bibliografia sobre a sua figura. Recordese, de relance, as palavras que lhe foram dedicadas por Maria Amália Vaz de Carvalho na biografia do Duque de Palmela ou o perfil que emerge dos estudos de Luís Xavier da Costa (COSTA, 1934 e 1938) e de Monsenhor José de Castro (CASTRO, 1939) ${ }^{6}$. De salientar a publicação, em 1919, coordenada por António Ferrão, da correspondência de D. Alexandre enquanto Ministro de Portugal na Corte de Frederico Guilherme II da Prússia, entre 1789 e 1790 - As impressões de um diplomata português na côrte de Berlim - e, de particular interesse para o nosso caso, para além do já referido estudo de Oliveira Martins (MARTINS, 1942), a grande publicação documental de Eduardo Brazão sobre as relações diplomáticas com a Santa Sé (BRAZÃO, 1973) ${ }^{7}$. Mais recentemente, algumas referências são-lhe feitas no catálogo da exposição Uma família de coleccionadores: poder e cultura, de novo no capítulo sobre o seu filho, D. Pedro de Sousa e Holstein.

\section{De Sanfré a Roma}

\footnotetext{
${ }^{5}$ Filha de D. Vicente José Roque de Sousa Coutinho Monteiro Paim e da sua primeira mulher, D. Teresa Vital da Câmara, nasceu em Lisboa em 1753 e morreu em Genebra a 10.4.1793, tendo sido sepultada em Sanfré. Foram seus filhos D. Pedro (1781-1850), futuro Duque de Palmela, D. Mariana Vicência (1784-1829), futura Condessa de Alva, D. Teresa Frederica (17861841), futura Condessa de Vila Real e Dama de D. Maria II e D. Catarina Juliana (1791-1971), futura Condessa de Linhares. ${ }^{6}$ Estes foram retomados em 2001 por Monsenhor Arnaldo Pinto Cardoso em A presença portuguesa em Roma.

${ }^{7} \mathrm{E}$ o estudo que lhe sobreveio no volume $A$ historiografia portuguesa anterior a Herculano, referindo-se especificamente às duas missões de D. Alexandre junto da Corte papal (BRAZÃO, 1977).
} 


\section{Imagem 3. Castelo de Sanfré (Cuneo, Piemonte, Itália).}

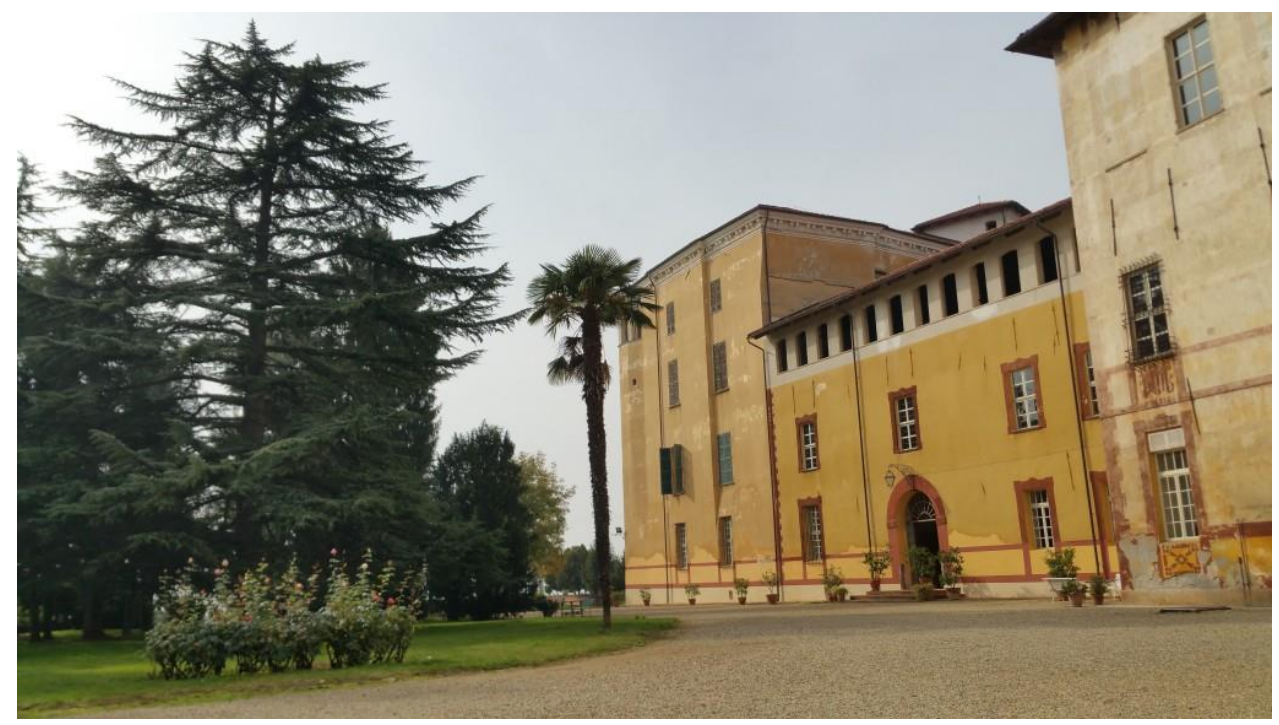

Imagem 4. Armas dos Sousa em Motta degli Isnardi (Cuneo, Piemonte, Itália).

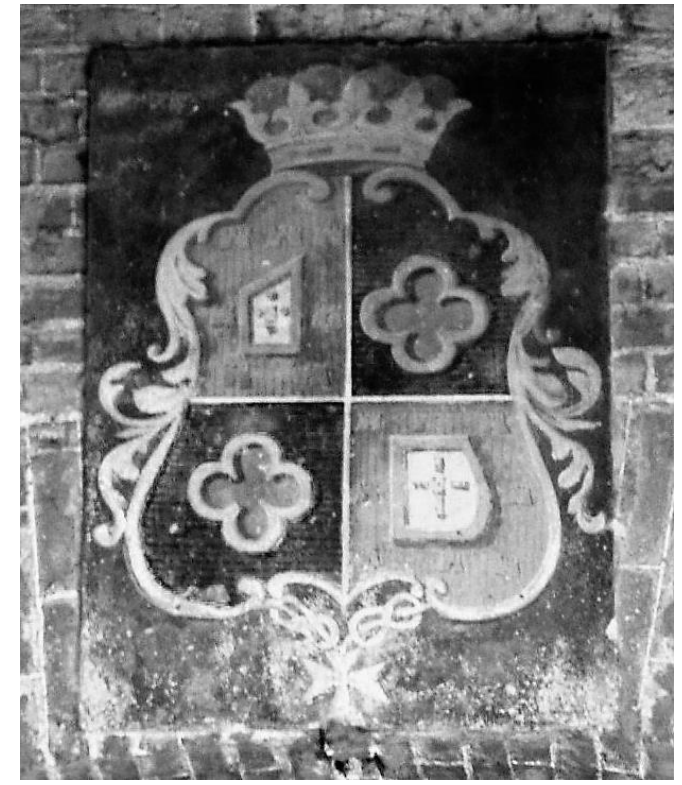

Vivendo no Piemonte desde muito jovem com a mãe, fugidos ambos à perseguição pombalina, só no reinado de D. Maria I é D. Alexandre autorizado a regressar a Portugal, onde casa com D. Isabel, conhecida antes do exílio. De Lisboa, onde lhe nascem os primeiros filhos, parte para a missão diplomática na Dinamarca em 1786, Corte em que goza do grande prestígio de ser aparentado, por via materna, da Casa reinante e tendo aí iniciado a sua boa relação com Pina Manique, a quem presta grandes serviços na vigilância zelosa que faz dos 
estudantes de cirurgia enviados pela Casa Pia para Copenhaga (cf. MARTINS, 1942, 380). No ano de 1789 toma posse plena de Sanfré, Motta e Isnardi por morte da mãe ${ }^{8}$, e, transferido para Berlim, será o primeiro Ministro português acreditado na corte do Rei da Prússia (FERRÃO, 1919). Mas, logo em 1790 partirá para Roma, como Ministro plenipotenciário junto da Santa Sé, no mesmo ano em que é investido de todos os morgadios da Casa de Sousa, por morte do irmão mais velho.

Noticiada pelo Diario Ordinario romano de 4 de dezembro de $1790^{9}$, a chegada de D. Alexandre era quase imediatamente seguida, na correspondência para o Ministro da Guerra e Estrangeiros, Luís Pinto de Sousa Coutinho, pelo pedido de uma licença para vir a Lisboa tratar das questões levantadas pela herança da sua rica Casa ${ }^{10}$ - deferido tardiamente ${ }^{11}$ e posto prática um ano e sete meses mais tarde ${ }^{12}$, numa viagem em que a mulher, doente, já não o acompanhou ${ }^{13}$.

Abreviada, portanto, esta primeira enviatura, e vivida num clima de latente agitação política, constituirá, todavia, um período importante para a história da Arte portuguesa, dado que ficará a dever a D. Alexandre, àquelas suas «qualidades de espírito, ilustração e bondade de alma» de artista e de erudito, de que falava Oliveira Martins, a institucionalização da

\footnotetext{
${ }^{8}$ Sobre a intrincada habilitação de herança, escreve GENTILE, 2014, 191-192: «En 1770, un procès s'ouvrit entre les Sousa et les Silva-Tarouca pour la succession aux fiefs de Sanfrè et Strevi, à la suite de la mort d'Angelo Isnardi, cousin de Maria Antonia de Schleswig-Holstein. Le Sénat de Piémont prononça en 1774 une première sentence qui ne contenta personne. On poursuivit, et le 20 mai 1791, enfin, Franz Stefan Silva Tarouca reçut 6/12 de Sanfré, 5/12 à Alexandre Sousa, le dernier 1/12 appartenant à d'autres familles. Pour cette raison, à Motta degli Isnardi, un complexe rural fortifié dans le territoire de la commune de Sanfré, on voit encore aujourd'hui les armoiries des Sousa (lignée de Sousa-Arronches), sur la porte du village et sur la façade de l'église de Santa Maria Maddalena.». Cf. também BONA, Federico, I da Sousa ei de Silva, presenze portoghesi in ambiente subalpino nel 1700 e 1800, pp. 22-23, disponível em $<$ http://www.socistara.it/studi/Bona Sousa Silva.pdf $>$, acesso em 03.04.2017.

9 «Proveniente in ultimo luogo da Firenze, nella sera dell'antecedente Giovedì giunse in Roma il Sig. D. Alessandro de Souza Holstein nuovo Ministro Plenipotenziario di S.M. la Regina Fedelissima a questa S. Sede incontrato a qualche distanza da Roma dal Sig. Cav. Pereyra, e andò a posarsi al Palazzo consueto presso S. Lorenzo in Pane, e Perna." Diario Ordinario, 04.12.1790, $\mathrm{n}^{\circ}$ 1662, p. 4. Ainda sobre a chegada, MARTINS, 1942, 381: «A 25 de outubro (sic) chegou, finalmente, a Roma o ministro acompanhado de D. Isabel e de seus filhos. Segundo Vieira (Portuense), bisbilhoteiramente anunciava a D. João de Melo e Castro, com quem se carteava amiúde, o conde de Sanfré fizera-se transportar em duas carroças de viagem, uma de dois lugares, onde vinha ele e a Senhora, e outra que era uma nova arca, onde vinha uma camareira que acompanhava os quatro filhos do Conde (...)"

${ }^{10}$ Pedido feito desde o primeiro ofício, a 1 de dezembro de 1790, de "uma licença a que as circunstâncias fatais da minha Casa me obrigam a pedir para ir a Portugal»: Arquivo da Embaixada de Portugal junto da Santa Sé (de ora em diante citada como A.E.P.S.S.), liv.VIII, fol. 1 ss. De notar que a documentação que se encontrava até 2016 no Arquivo histórico da Embaixada junto da Santa Sé foi enviada para o Ministério dos Negócios Estrangeiros em Lisboa, onde se crê que em breve todo o fundo estará disponível. A indicação que aqui fazemos refere-se à antiga localização, onde a documentação foi consultada.

${ }^{11}$ Licença concedida a 19 de outubro de 1791, que espera aproveitar, "pois tendo alguns negócios em Turim, partirei para aquela Cidade no corrente Inverno, e de lá para Portugal no princípio da Primavera»: A.E.P.S.S., liv. VIII, fol. 45 ss.

${ }^{12}$ A 9 de fevereiro de 1791, a ressalva: a ida a Portugal concretizar-se-á apenas quando não tiver «(...) aqui negócios de importância que tratar em nome de Sua Majestade (como agora sucede). Rogo a V.Ex. ${ }^{a}$ que suplique à mesma Senhora me conceda a licença qu eu lhe peço desde agora para me prevalecer dela quando a circunstância o permitir, sem deterimento do seu Real serviço.» A.E.P.S.S., liv. VIII, fol. 8 ss. De facto, a partida programada para finais de fevereiro de 1792 «ficará deferida ulteriormente se a saúde de Sua Santidade se não restabelecer perfeitamente neste intervalo" (14 de dezembro de 1791, A.E.P.S.S., liv. VIII, fol. 52 ss.) e também "pelo infeliz estado de saúde de minha mulher" (22 de fevereiro de 1792 , A.E.P.S.S., liv. VIII, fol. 62 ss.).

${ }^{13}$ Morreria dali a pouco mais de dois anos na Suíça, onde ficara a tratar-se. «Seus filhos, acompanhados por um perceptor e uma criada de confiança, foram para Londres. Só em 1795, a bordo da "Rainha de Portugal", do comando do Marquês de Nisa, arribaram ao Tejo.» (BRAZÃO, 1973 I, 18).
} 
aprendizagem dos artistas nacionais, com a fundação da chamada "Academia portuguesa de Belas-Artes em Roma".

\section{O tempo e o espaço de D. Alexandre}

Símbolo de reação anti-pombalina, os anos do reinado de D. Maria I foram em Portugal de importante fermento cultural (cf. SERRÃO, 1982, 438-458 e SERRÃO, 1981, 704-706), a par de preocupações de caráter militar e diplomático, que a independência dos Estados Unidos da América e as tensões que leveram à Revolução Francesa determinaram. Nos dez anos que precederam a chegada do nosso diplomata a Roma é fundada a Casa Pia de Lisboa, que começa a funcionar no Castelo de São Jorge, cria-se no Porto a Aula de Desenho e Debuxo e inaugurase a Academia do Nú (1780); a Academia das Ciências lança as bases de um Museu de História Natural (1781), inicia a atividade do Observatório Astronómico da Academia das Ciências (1787), a Nova Arcádia nasce em substituição da Arcádia Lusitana (1790) e vêm a lume inúmeras publicações científicas ${ }^{14}$. É dentro deste quadro que deve ser entendida a ação cultural romana de D. Alexandre, condicionada embora pela tensão que a política francesa fazia já sentir em Roma.

Disso mesmo darão testemunho os ofícios que dirige, desde dezembro de 1790, para Lisboa: enquanto Portugal se mantinha expetante sobre o rumo da Monarquia Constitucional francesa (SERRÃO, 1982, 310), esta correspondência, particularmente circunstanciada, punha o País a par das tensas relações entre Pio VI e a França ${ }^{15}$. Com o Breve Quod aliquantum de 10 de março de 1791, endereçado aos bispos signatários da Exposition des principes sur la Costituition civile du clergé (30 de outubro de 1790), o Papa condenava toda a ação da Assembleia constituinte em campo eclesiástico, mas também os princípios de liberdade e igualdade que a tinham guiado, tidos como contrários ao caráter divino da organização social (cf. LEFLON, 1971, 85-124):

Il breve di condanna e il tempo intercorso per la sua emanazione aggravarono la frattura in corso in Francia tra clero refrattario e clero costituzionale, con la contrapposizione tra due culti cattolici e due Chiese, e diedero avvio alla rottura tra cattolicesimo romano e Rivoluzione destinata a durare oltre il concordato napoleonico e ad

\footnotetext{
${ }^{14}$ Entre elas, o primeiro compêndio Elementos de Química de Vicente Coelho Seabra (1788), iniciam as Memórias Económicas, da Academia das Ciências e o Dicionário de Morais e Silva (1789), surge em Lisboa $O$ Comércio Mercantil e Económico de Portugal e os Princípios Matemáticos de José Anastácio da Cunha (1790).

${ }^{15} \mathrm{Na}$ base desta tensão estava a aprovação, a 12 de julho de 1790, pela Assembleia francesa, da Constituição civil do clero, que reorganizava inteiramente a Igreja galicana como igreja nacional, subordinada, portanto às decisões dos colégios eleitorais departamentais. A uma primeira tentativa, vã, de intervir junto de Luís XVI da França, à promulgação da Constituição em setembro e à imposição, em novembro, da obrigação do clero de prestar juramento de fidelidade à nação, ao rei e à nova lei, segue-se finalmente uma reação de Pio VI, que até então se mantinha em prudente silêncio (cf. PASTOR, 1955, 460-497).
} 


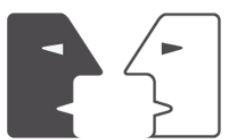

ANTÍTESES

influire anche sugli eventi successivi. Inoltre, un breve ulteriore, Charitas, indirizzato ai vescovi di Francia e accompagnato da una lettera al re Luigi XVI (13 aprile 1791), respingeva il giuramento civico per gli ecclesiastici, sospendeva quanti non avessero ritrattato e annullava le nomine dei vescovi fatte senza l'accordo del pontefice. Le relazioni ufficiali con la Francia furono rotte nel maggio dello stesso anno, quando, dopo il rifiuto di Pio VI di accettare il nuovo ambasciatore che sostituiva il cardinale de Bernis, il nunzio a Parigi monsignor Antonio Dugnani, a seguito di una violenta manifestazione popolare in cui venne bruciato un manichino raffigurante il pontefice, lasciò la Nunziatura. Mentre Pio VI accoglieva a Roma le zie emigrate del re e manifestava imprudentemente la sua gioia per la notizia della fuga di quest'ultimo (con lettera del 6 luglio 1791), la Francia proclamava, nel novembre, l'annessione dei due territori pontifici di Avignone e del Contado Venassino, ignorando le proteste del papa contro questo primo attacco alla sua sovranità temporale. (CAFFIERO, 2000, p.502)

\section{Imagem 5. Pio VI, Giannangelo Braschi (1717-1799)}

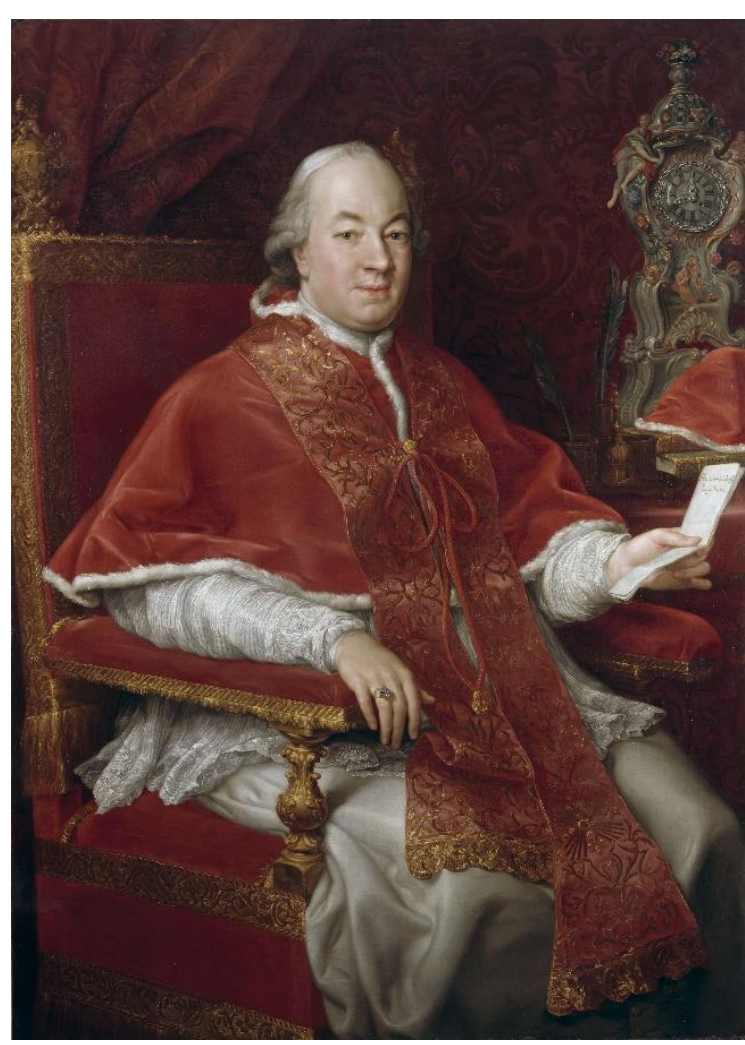

Fonte :Retratado por de Pompeo Batoni em1775, óleo s/ tela, $137 \times 98 \mathrm{~cm}$, National Gallery of Ireland 
D. Alexandre disserta sobre a lentidão de resposta do Papa relativamente à Constituição civil do clero e dos seus efeitos perniciosos ${ }^{16}$, do Breve Charitas $^{17}$, do acolhimento das Mesdames Tantes em Roma ${ }^{18}$, da alegria que a notícia da fuga do rei de França causou na Cidade ${ }^{19} \mathrm{e}$ enfim, da anexão dos territórios papais em França ${ }^{20}$. Será ele também, a 1 de junho de 1791, a noticiar a interrupção das realções diplomáticas entre a Santa Sé e a França ${ }^{21}$. Estas a par de informações de interesse nacional, como as que se referem a Luís António Verney ${ }^{22}$ que, muito idoso, obtivera a nomeação como deputado honorário do Tribunal da Mesa de Consciência e Ordem em 1790, com uma tença anual de 480 mil reis (A.E.P.S.S., liv. VIII, fol. 24 v., ss. e ANDRADE, 1966), e que morrerá em Roma ${ }^{23}$ - ou as reações à doença de D. Maria I e à regencia de D. João VI (A.E.P.S.S., liv. VIII. fol. 64 v. ss.).

\section{Dezassete meses romanos para a história da cultura portuguesa}

A ação de D. Alexandre em prol da cultura nacional durante a sua primeira enviatura a Roma caracteriza-se principalmente pela conceção e organização da Academia portuguesa de Belas-Artes. Todavia convém notar que tal ação não se restingiu às artes plásticas, mas se expandiu, à imagem da erudição do diplomata, em âmbitos variados - como por exemplo o da música, quando se viu envolvido, com a mulher, na escolha dos castrati a enviar para a Corte ${ }^{24}$.

\footnotetext{
${ }^{16}$ "Ainda não se expediu o Correio de França que deve levar a resposta do Santo Padre a El-Rei, e não se entende no público qual seja a razão de tanta demora (...)", 29.12.1790, A.E.P.S.S., liv. VII, fol. 4 v., ss.

${ }_{17}^{17}$ "Também oiço que se está imprimindo na Oficina Pontifícia o Breve que Sua Santidade está para expedir aos novos Bispos de França (...)" 13.04.1791, A.E.P.S.S., liv. VIII, fol. 14 v., ss.

${ }^{18}$ "Chegaram há três dias a esta Corte as Princesas tias de El-Rei de França, a quem o Papa tem feito todas as atenções (...)" 20.04.1791, A.E.P.S.S., liv. VIII, fol. 16, ss.

19 «Não se pode exprimir a alegria e os transportes que causou esta notícia em Roma (...) O Papa (...) ficou também excessivamente alegre com a inesperada notícia da sua libertação e mandou imediatamente o Cardeal Nepote cumprimentar da sua parte as Princesas de França e o Cardeal Bernis.» 06.07.1791, A.E.P.S.S., liv. VIII, fol. 29, ss.

20 «(...) tendo porém grande parte parte nestes discursos a usurpação de Avinhão e do Condado de Venaissin, aonde neste ponto reina a mais atroz confusão.» 26.10 .1791 , A.E.P.S.S., liv. VIII, fol. 46, ss.

${ }^{21}$ «(...) escreveu a Secretaria de Estado ao Núncio que o Santo Padre não receberia absolutamente o Embaixador Mr. Ségur, proposto por El-Rei de França, nem algum outro que houvesse prestado o juramento cívico, como Sua Santidade já havia declarado a El-Rei. Esta determinação (...) fecha de uma só vez a porta a qualquer sorte de negociação entre a Cúria Romana e a Corte de França (...)": A.E.P.S.S., liv. VIII, fol. 46, ss.

${ }^{22}$ Luís António Verney (1713-1792) mestre em Artes pela Universidade de Évora, viera para Roma por volta de 1736, cidade onde se licencia em Teologia. Aqui começou também a preparar $O$ verdadeiro método de estudar, em que teorizava a reforma que entendia necessária do ensino universitário em Portugal.

${ }^{23}$ Como participa a 21 de março de 1792: «Recebo neste ponto a participação da morte do Cavaleiro Luís António Verney que passou ontem para melhor vida às 3 horas depois do meio-dia, e como não deixou aqui cabedal algum, nem tão pouco dívidas, foi necessário que recorressem a mim pedindo-me dinheiro para as suas exéquias.» (A.E.P.S.S., liv. VIII, fol. 65 v., ss.).

${ }^{24}$ Carta de José Pereira Santiago ao Guarda-joias da Rainha, de 1 de dezembro de 1790: «e tendo aqui chegado o Ex. $\mathrm{m}^{\circ} \mathrm{Sr}$. Dom Alexandre Ministro Plenipotenciário e a Sr. ${ }^{a}$ D. Isabel Sua Mulher entende muito a música, assentamos, que Checchino de Verni viesse aqui cantar um dia diante da Senhora para que também ela desse o seu voto" (CARVALHO, 1922, 74). De novo, a 2 de fevereiro seguinte «se efetuou na sexta-feira à noite o concerto nesta casa e nela se cantou não só Capranica mas também Checchino, e ouvi logo dizer à Senhora que Checchino além de maior fundo de música é muito
} 
A primeira referência interessante de $D$. Alexandre sobre o também denominado “Colégio Português de Belas-Artes de Roma" para o Ministério, data de 7 de dezembro de 1791:

\begin{abstract}
Deste estabelecimento, se com efeito se sustentar (como todos os bons patriotas devem desejar), retirarão os artistas nacionais as maiores vantagens, e já presentemente se acham aqui entre outros alunos quatro pintores, um escultor, um abridor e um incisor de camafeus, de cujo número certamente não haverá um só que não chegue a um grau superior de merecimento; por cujo motivo invoco os bons ofícios de V.Ex. ${ }^{a}$ e reclamo a protecção especial de Sua Majestade para a conservação desta Academia, instituída já com maior fausto e menor vantagem dos Artistas em tempo do seu glorioso Avô, o Senhor D. João V.
\end{abstract}

(A.E.P.S.S., liv. VIII. fol. 51 ss.)

Mais expressiva é a sua escrita quando o Interlocutor é Diogo Inácio de Pina Manique ${ }^{25}$, o Intendente-geral da Polícia que inspirara a D. Maria I a fundação da Casa Pia a 20 de maio de 1780, onde se havia de fundar a Aula Pública de Desenho, a cargo dos mestres Joaquim Manuel da Rocha e Eleutério José de Barros, e que foi a base da Academia do Nu. Se para «Londres, Edimburgo e Copenhaga seguiram os jovens dotados em medicina, cirurgia e partos" (SERRÃO, 1982, pp.443-444), para Roma seguiriam os aspirantes a artista. Nesta correspondência pode-se identificar não só a clareza institucional com que D. Alexandre organizou esses rapazes, mas também preciosas indicações biográficas sobre os mesmos, e, nas entrelinhas, o seu espírito requintado de entendedor das artes, que se prezava «ser meio arquiteto" e continuador da tradição familiar do colecionismo ${ }^{26}$.

mais animado, e expressivo no cantar, o que não tem o outro (...)" (CARVALHO, 1922, 79). Sobre os castrati italianos em Portugal cf. AUGUSTIN, Kristina, "A trajetória dos castrati nos teatros da corte de Lisboa (séc. XVIII)" in Revista Música e Linguagem - Vitória/ES. Vol.1 n 3 (2013), p.73-94.

${ }^{25}$ Como justamente nota Oliveira Martins «cartas (...) nas quais o diplomata desafiou os seus pensamentos acerca dos processos de ensino e projetos da constituição da "Academia Portuguesa de Roma"» (MARTINS, 1942, p. 375).

${ }_{26}$ «Homem de cultura, incrementou várias escavações arqueológicas levadas a cabo perto do Coliseu de Roma enriquecendo as colecções da família com mosaicos romanos, vasos helenísticos, entre outras peças.» (PAIS, 2001, 144). Neste particular, Maria de Sousa e Holstein Campilho segue certamente as indicações fornecidas em CARVALHO, $1898,91$. Eduardo Brazão parece ser o mais cético possível relativamente aos méritos arqueológicos de D. Alexandre: "Quanto às escavações feitas pelo Embaixador, temos ainda mais dúvidas, pois não parece possível que tendo estado de cada vez um ano e sete meses apenas, com visitas protocolares, redação de longos Ofícios preparados com toda a espécie de informação que colhia, arranjo das casas à chegada longos preparativos à partida, ainda Alexandre de Sousa tivesse tempo para se dedicar a escavações!» (BRAZÃO, 1973, nota 23 p.21). Brazão omite ainda a organização da Academia em que, como veremos, o diplomata parece dar o melhor de si. 


\section{Imagem 6. “Chiesa e monastero di S. Lorenzo in Panisperna delle suore francescane osservanti"}

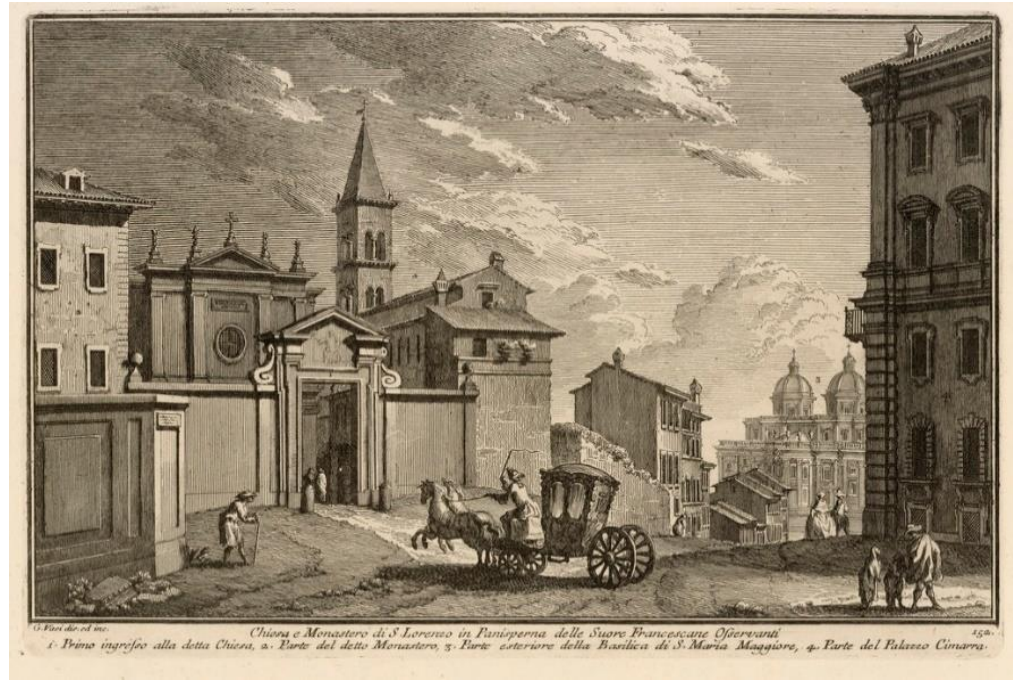

Fonte: Gravura de Giuseppe Vasi, em Delle magnificenze di Roma antica e moderna ... (1747-1761). À direita $\left(n^{\circ} 4\right)$, parte do Palazzo Cimarra, onde esteve instalada a Academia de Portugal

\section{A Academia}

A história desta Academia tem vivido, desde a publicação em 1823 da Collecção de memórias de Cirilo Volkmar Machado, na maior confusão ${ }^{27}$, devida à repetição de imprecisões e erros e à escassez de documentos que deitem nova luz sobre o problema ${ }^{28}$ - sendo o primeiro o da sua localização ${ }^{29}$.

\footnotetext{
${ }^{27}$ Caso paradigmático parece ser o de Amy Allemand Bernardy, que confunde a fundação joanina de meados do séc. XVIII com a nova Academia: cf. BERNARDY, 1941, 74.

${ }^{28}$ Esperamos, pois, ansiosamente, os resultados da investigação doutoral de Michela Degortes, que tem por título "Giovanni Gherardo De Rossi (1754-1827) na direção da Academia Portuguesa de Belas-Artes em Roma: Ensino e Mercado da Arte». Interessantes os dois artigos já publicados (cf. particularmente DEGORTES, 2016), e as seguintes apresentações: no convénio internacional "Corrispondenze d'artista: Roma e l'Europa (XVIII-XIX secolo)", 2015, "La Real Accademia Portoghese di Belle Arti a Roma nella corrispondenza dei diplomatici, degli artisti e del direttore Giovanni Gherardo De Rossi»; nas $3^{\text {a }}$ Jornadas ARTIS, 2016, "Relações luso-italianas em torno da Academia Portuguesa de Belas Artes em Roma: a figura de Giovanni Gherardo De Rossi»; no III Colóquio Internacional "Coleções de Arte em Portugal e no Brasil nos séculos XIX e XX”, 2016, "Ensino artístico no estrangeiro e relações internacionais: o caso da Academia Portuguesa de Belas Artes em Roma" e ainda no convénio "A Casa Senhorial Anatomia de Interiores", 2016, "Aquisição de moveis e ornamentação para a residência de um diplomata: o gosto de Alexandre Sousa Holstein".

${ }^{29}$ A confusão parte da memória de um "palácio junto a S. Lourenço in Panisperna, habitado pelo Comendador Francisco de Almada e Mendonça, entre 1756 e 1757». Este será de novo alugado por D. João de Almeida de Melo e Castro (1788-1790) e por D. Alexandre (1790-92). Será o Secretário deste último, que lhe sucederá como Encarregado de Negócios, a habitar o Palazzo Cimarra, onde esteve instalada a Academia e onde durante as incursões francesas ficaram muradas as pratas e os demais objetos da Legação (cf. CASTRO, 1939, II, pp-365-366 e BRAZÃO, 1973, II, pp.404-546). Resta identificar o palácio alugado para a habitação dos Embaixadores, que cremos poder identificar naquele situado no atual $\mathrm{n}^{\circ} 207$ da via Panisperna.
} 
Já o antecessor de D. Alexandre ${ }^{30}$, fora encarregado de dar uma disciplina aos alunos que a Casa Pia de Lisboa vinha enviando para Roma desde $1785^{31}$, retirando a direção dos rapazes a Carlo Maria Marruchi (cf. COSTA, 1938,1-3), colocando-os sobre a vigilância dos padres David Peres (A.E.P.S.S., liv. VIII, fol.12) e Gregório Pedro Pereira ${ }^{32}$ e instalando-os em sua casa ${ }^{33}$. Sousa e Holstein encontra ali oito alunos da Casa $\mathrm{Pia}^{34}$, e refere:

(...) quanto ao seu caráter, e ao procedimento de cada um deles não é possível dizer senão mil bens (...) mas apesar disso não posso deixar de confirmar a V.S. com grande sentimento meu (...) da impossibilidade em que me vejo de os continuar a conservar nesta casa.(MARTINS, 1942, 395)

Logo em junho se ia "cuidando em lhes procurar um aposento cómodo e suficiente nas vizinhanças desta casa, a fim de que me não saiam muito da vista, e espero que se poderá alugar uma que está meia apalavrada pelo preço de 30 ou 35 moedas.» (MARTINS, 1942, 395). A casa, alugada em agosto pela renda mensal de 25 escudos $^{35}$, ficava em frente a San Lorenzo in Panisperna, e era composta por dois andares nobres, dois entressolos e uma varanda descoberta. E tratou-se então de apetrechá-la «com abundância de material didático e artístico, em grande parte proveniente das coleções do célebre mestre António Rafael Mengs, falecido

\footnotetext{
${ }^{30}$ Nomeado ainda em 1787, D. João de Almeida, $5^{\circ}$ Conde das Galveias, chega a Roma a 5 de dezembro do ano seguinte e é recebido com aparato (CASTRO, 1939, p. 40), para logo em 1790 se ver transferido para Londres.

31 Pina Manique demonstra já claramente "um programa" nas cartas para D. João (VALENTE, 1950, 260). Porém provavelmente só em D. Alexandre irá encontrar um interlocutor em sintonia: "No caso do programa de artistas pensionados no estrangeiro promovido por Pina Manique, o facto de assentar numa certa noção de progresso e de ter objetivos definidos, não chegaria a transformar a iniciativa numa verdadeira instituição de ensino. Para o efeito contouse com o apoio da rede diplomática, cuja importância no âmbito das trocas culturais e artísticas entre países é indiscutível, e neste sentido, não é exceção o caso em análise: o pensionato dos artistas no estrangeiro está ligado à visão e expertise dos seus referentes no país anfitrião.» (DEGORTES, 2016, 138).

${ }^{32}$ Coletor e Deputado da igreja nacional em Roma, «Dom Gregório Pedro Pereira era um religioso egresso da Congregação dos teatinos e foi arquivista da Legação de Portugal e quase no fim da vida foi nomeado Governador de S. António e Prelado Doméstico de Sua Santidade» (CASTRO, 1939, 121).

${ }^{33}$ «Melo e Castro rapidamente pôs cobro aos desatinos, começando o saneamento por instalar os rapazes debaixo das suas vistas, numa dependência da própria morada. Daí partiriam de futuro os estudantes a frequentar as logeas dos mestres que escolhessem, segundo a sua vontade, porquanto, até então, os alunos haviam tido por único mestre de desenho Labruzzi, cujos talentos eram muito discutíveis. (...) Tiveram os rapazes de Roma, entre outros, por professores: na pintura e desenho, Tomás Pedro Labruzzi (sic). Os gravadores, Pedro Vitali e Volpato, os escultores José Angelini e António Canova e o arquiteto João Antinori.» (MARTINS, 1942, 379).

${ }^{34}$ Tratava-se do miniaturista José Álvares (ou Alves) de Oliveira, dos pintores José da Cunha Taborda, Arcangelo Fuschini e Bartolomeu António (da Costa) Calisto, do escultor João José de Aguiar, dos gravadores José António do Vale (abridor de camafeus) e José Caetano Rivara (abridor de estampas) e do arquiteto António Joaquim Lopes de Sousa. Há uma ambiguidade na conta, pois D. Alexandre refere-se a 8 alunos, mas fala genericamente em três gravadores, faltando nesta lista António Sizenando Pinto, que sabemos ter endoidecido em Roma. Para além destes, alunos da Casa Pia - e por isso mencionados na carta ao Intendente, estavam em Roma o ex-beneditino José Teixeira Barreto, subsidiado pessoalmente pelo diplomara, Sequeira financiado pelo Real Bolsinho e Vieira Portuiense com bolsa da Companhia dos Vinhos do Douro. (Cf. MARTINS, 1942, 394-395).

${ }^{35}$ Recibos passados pelo procurador dos Nobili Fratelli Amadei (A.E.P.S.S., caixa 28, maço I, ms. 1 e 7).
} 
em 1779, e do pintor e gravador Johann Pichler, falecido no referido ano de 1791» (COSTA, 1934, p.96).

De facto, na carta que endereça a 28 de dezembro de 1791 a Pina Manique, D. Alexandre refere a "compra de muitas coisas essenciais, e indispensáveis para a Academia, quais são os gessos das principais estátuas clássicas de Roma " ${ }^{36}$, acrescentando que "não pude deixar de autorizar várias despesas, que eu mesmo houvera feito para benefício da Academia se me achasse no Lugar de V.S.», confessando que concorrera "com alguma soma de dinheiro meu próprio tanto para alívio dessa Casa Pia, quanto para benefício comum da Pátria", para que a Academia não desse só "pousada" aos alunos, mas também "o cómodo de estudar copiando os seus gessos, e debuxando o nu; e assistindo às práticas, ou dissertações sobre as belas-artes em geral, e sobre cada uma em particular que o Sr. João de Rossi pronuncia três vezes por semana na mesma Academia» (MARTINS, 1942, p.398).

\section{Mestres da Antiguidade e da atualidade}

Um dos problemas postos por $\mathrm{D}$. Alexandre a Pina Manique é aquele onde, na sua opinião, radicava a mediocridade dos resultados de certos alunos, ainda que naturalmente dotados: 0 facto de se encontrarem sobre a égide de um só mestre. Sancionado por doutas opiniões que consultara, o diplomata confere à frequência dos professores essencialmente um aval sobre os progressos dos jovens, cuja aprendizagem se faria copiando os grandes Mestres do passado e frequentando a Academia do $\mathrm{Nu}^{37}$ :

em consequência deste plano entrarão os rapazes a copiar pelas galerias os originais de Rafael, e de Tiziano que é o que os mestres não querem, pois faz mais conta que desgrossem as suas obras o que é somente bom para os principiantes; e assim o experimento depois que ordenei a

\footnotetext{
${ }^{36} \mathrm{Na}$ carta de 14 de setembro de 1793 ao Presidente do Real Erário, Pina Manique junta a referência ao espólio de Batoni: "tendo também a Casa Pia de Lisboa comprado todos os gessos de estátuas, e lavores de Pompeo Batoni, célebre pintor dos nossos tempos; e de outros mestres desta linha, que paravam dispersos em mãos de terceiros, com que se ornou uma grande sala do palácio da mesma Academia e servem ao mesmo tempo para o Estudo; tudo debaixo da inspeção, e vistas patrióticas de D. Alexandre de Sousa" (MARTINS, 1942, 392).

${ }^{37} \mathrm{~A}$ irá perorar, de facto, que os alunos «se não prendam a trabalhar somente em casa um mestre, pois não é possível que façam progressos na escola de um pintor mediocre (...) Ordenei portanto que daqui em diante se não ocupassem em outra coisa além da Academia do Nú se não em copiar continuamente as pinturas de Rafael nas Cameras do Vaticano, pois não há escola melhor que a imitação, e observação das obras daquele grande homem. Esta prática, e os conselhos de seus Mestres a quem podem mostrar as suas obras deve necessariamente fazer deles bons pintores ou não há meio de os fazer tais. Necessito dizer a V.S. q. esta determinação não foi tomada somente por meu juízo, mas por conselho dos melhores pintores de Roma que consultei para não errar» (MARTINS, 1942, p.394).
} 
Cunha $^{38}$, e a Fuschini ${ }^{39}$ que fossem copiar para mim alguns quadros da Galeria do Capitólio, dando-lhes todo o preciso, e algum pequeno prémio para os animar. (MARTINS, 1942, p.396)

O mesmo vinha fazendo Domingos António de Sequeira ${ }^{40}$, que vivia na Urbe havia já mais de dois anos ${ }^{41}$ quando D. Alexandre chegou, e fora recebido no palácio da Legação pelo então Encarregado de Negócios, José Pereira Santiago - o mesmo que, logo em setembro de 1788, manda dizer para Lisboa que o jovem já começara a «observar algumas pinturas que lhe vão a génio neste Capitólio, e galerias de Príncipes; e se vai aperfeiçoando com toda a curiosidade sem que se poupe ao trabalho" (CARVALHO, 1922, 10-11) ${ }^{42}$.

\section{Sequeira e Holstein}

Antes da chegada de D. Alexandre, a 17 de março de 1789, Sequeira vencera o $2^{\circ}$ prémio da Academia do $\mathrm{Nu}$ do Capitólio e logo a 25 de maio o $2^{\circ}$ prémio da classe de pintura do Concurso Clementino, com o desenho Milagre da multiplicação dos pães e dos peixes e outros dois desenhos do Sacrificio de Isaac elaborados nas duas horas da prova (CORREIA, 1923, 19-31). Não só avançava na cópia dos grandes Mestres, preconizada pelo diplomata, mas começava também a estar integrado no mundo artístico romano, fazendo inclusivamente amizade com Luigi Agricola, que vencera o primeiro prémio do Concurso Clementino ${ }^{43}$. Apesar disso, o Guarda-joias da Rainha escreve a 29 de março de 1791 para "introduzir" o artista a D. Alexandre (CARVALHO, 1922, 101-102) ${ }^{44}$, que lhe responde a 27 de abril:

\footnotetext{
${ }^{38}$ José da Cunha Taborda (1766-1836).

${ }^{39}$ Arcangelo Fuschini (1771-1834).

${ }^{40}$ Uma carta de 1 de setembro de 1790 de Vieira Portuense refere-se à frequência de outras pinacotecas romanas por parte de Sequeira - «anda procurando licença para ir para a Galeria Collona podendo estar na Corsini» (cf. CARVALHO, 1996, 106). ${ }^{41}$ Partindo de Lisboa em maio de 1788, subvencionado pelo Real Bolsinho de D. Maria I, traz uma carta de recomendação de João António Pinto da Silva, Guarda-jóias da Rainha, para o cônsul de Portugal em Génova, para que se lhe paguem "dez mil reis em cada um mês» (CARVALHO, 1922, 1). Chega a Roma a 29 de junho.

${ }^{42} \mathrm{E}$ em outubro, numa escursão a Grotta Ferrata, «em 4 dias desenhou toda a capela de Domenichino com admiração dos intendentes e de 3 ingleses que ali estudavam" - concluindo: "Graças a Deus que já vejo um moço português dar nome" (CARVALHO, 1922, 12).

${ }^{43}$ Numa carta de 26 de outubro de 1790 para D. João de Almeida, diz que «tenho feito estudo junto com o Agricola do homem nu com tintas por que é o que V. Ex. ${ }^{a}$ me recomendou muito" (cf. CARVALHO, 1996, 106). Encontraremos mais tarde este pintor em 1801 - em substituição de Giuseppe Cades, a quem primeiro se dirigira a encomenda - a trabalhar para a igreja nacional em Roma, no retábulo da Rainha Santa Isabel (cf. ROCCA-BORGHINI, 1992, 167-168).

${ }^{44}$ Talvez devida a uma primeira referência pouco lisonjeira de Sequeira sobre D. Alexandre, a 2 de fevereiro de 1791, a D. João de Almeida - o diplomata não só lhe pedira o esboceto "do quadro de invenção que mandei para a Rainha" ( $A$ Moeda de César) mas também que, ao contrário do que aquele antigo Ministro fizera - «que me dava sempre uma vez o jantar outra o almoço e outras tantas como vestido me levava fora" - a parcimónia de D. Alexandre não lhe permitia poupar (cf. CARVALHO, 1996, 106).
} 
O pintor Domingos Sequeira, que Vossa Senhoria me recomenda não precisava do seu favor para eu haver de o proteger em tudo o que posso pois merece por si mesmo todo o agasalho e favor, mas é certo que a recomendação de que Vossa Senhoria o honra não pode deixar de lhe ser muito proveitosa... (CARVALHO, 1922, 106)

Serão estes os anos em que Sequeira concebe e produz os seus grandes painéis do Milagre de Ourique (hoje em França, Museu de Eu) e Pregação de S. João Baptista (Vila Viçosa, Paço dos Duques de Bragança) e também aqueles em que provavelmente o artista será professor de arte dos filhos de D. Alexandre ${ }^{45}$. Em simultâneo com a partida do diplomata para Portugal, em julho de 1792, Sequeira deslocar-se-á para Nápoles, como terapia para as «convulsões nervinas nos olhos e contínuas dores de cabeça" de que padecia (CARVALHO, 1922, 115-116), dali regressando quatro meses depois e iniciando em novembro os estudos para o quadro encomendado por Pina Manique - Alegoria à Fundação da Casa Pia (cf. CARVALHO, 1996, 107). Será depois da estadia e da convivência com Sousa e Holstein, talvez por sua influência e de Giovanni Gherardo De Rossi, que a 2 de agosto de 1793 o pintor faz requerimento à Academia de São Lucas, onde virá a ser aceite "a pieni voti" ${ }^{46}$ na sessão que a Congregação reúne a 6 de outubro desse mesmo ano (CORREIA, 1923, 32-38) ${ }^{47}$.

\footnotetext{
45 "A Sequeira, no pronto conhecimento das suas grandes qualidades de pintor, D. Alexandre escolheu para mestre dos seus filhos.» MARTINS, 1942, p.382. A preocupação de D. Alexandre com a cultura artística dos filhos é sublinhada por António Ventura, referindo-se ao futuro Duque de Palmela, durante a segunda enviatura do pai a Roma: «No Outono daquele ano (1802), instalavam-se na Cidade Eterna, num regresso que muito agradou ao jovem aprendiz de diplomata, que tinha em seu pai um guia, um amante e protector das Belas Artes: "o interesse que excitavam no meu ânimo os passeios que, com meu pai e os mais célebres antiquários de Roma, eu dava quase diariamente, visitando as ruínas da capital do mundo, aumentava com a leitura que nesse tempo começava a fazer da História Antiga e Romana. Outra excitação também resultava para mim da frequência dos alunos da academia portuguesa de belas artes, instituída por meu pai em Roma"” (PAIS, 2001, p.45). E ainda "José Alves (ou Álvares) de Oliveira (...) no final de 1790 ainda estava na comunidade artística e, juntamente com Francisco Vieira, o Portuense, servia de "cicerone" aos filhos do ministro Dom Alexandre de Sousa Holstein nas suas digressões pela cidade" (COSTA, 1934, p.153).

${ }^{46}$ Feito Académico e Mérito e Professor da Academia Romana, tendo entre os votantes Francesco Navone - arquiteto responsável pelas obras da igreja nacional de Portugal desde 1770 até à sua morte, em 1803, e secretário da Academia Antonio Cavalucci - um dos mestres de José da Cunha Taborda, pensionista da Academia - e Giuseppe Cades - mestre de José Teixeira Barreto e a quem em 1798 fora confiado o retábulo da Rainha Santa Isabel em Santo António dos Portugueses, de que faz apenas os esboço, tendo morrido nesse mesmo ano (cf. ROCCA-BORGHINI, 1992, 167-168). A introduzi-lo nas reuniões da Congregação de São Lucas estava Antonio Concioli, o autor das pinturas da Capela da Natividade e da tela representando Coração de Jesus encomendadas pela Congregação de Santo António dos Portugueses (cf. idem, 89-95 e 180). ${ }^{47}$ Apresentando para ser admitido A degolação de S. João Baptista, irá depois frequentar as reuniões com intervalos até 27 de maio de 1795, data da sua partida para Génova, e dali para Lisboa (CARVALHO, 1922, CLIV).
} 


\section{Imagem 7. “Alegoria da Fundação da Casa Pia de Belém”}

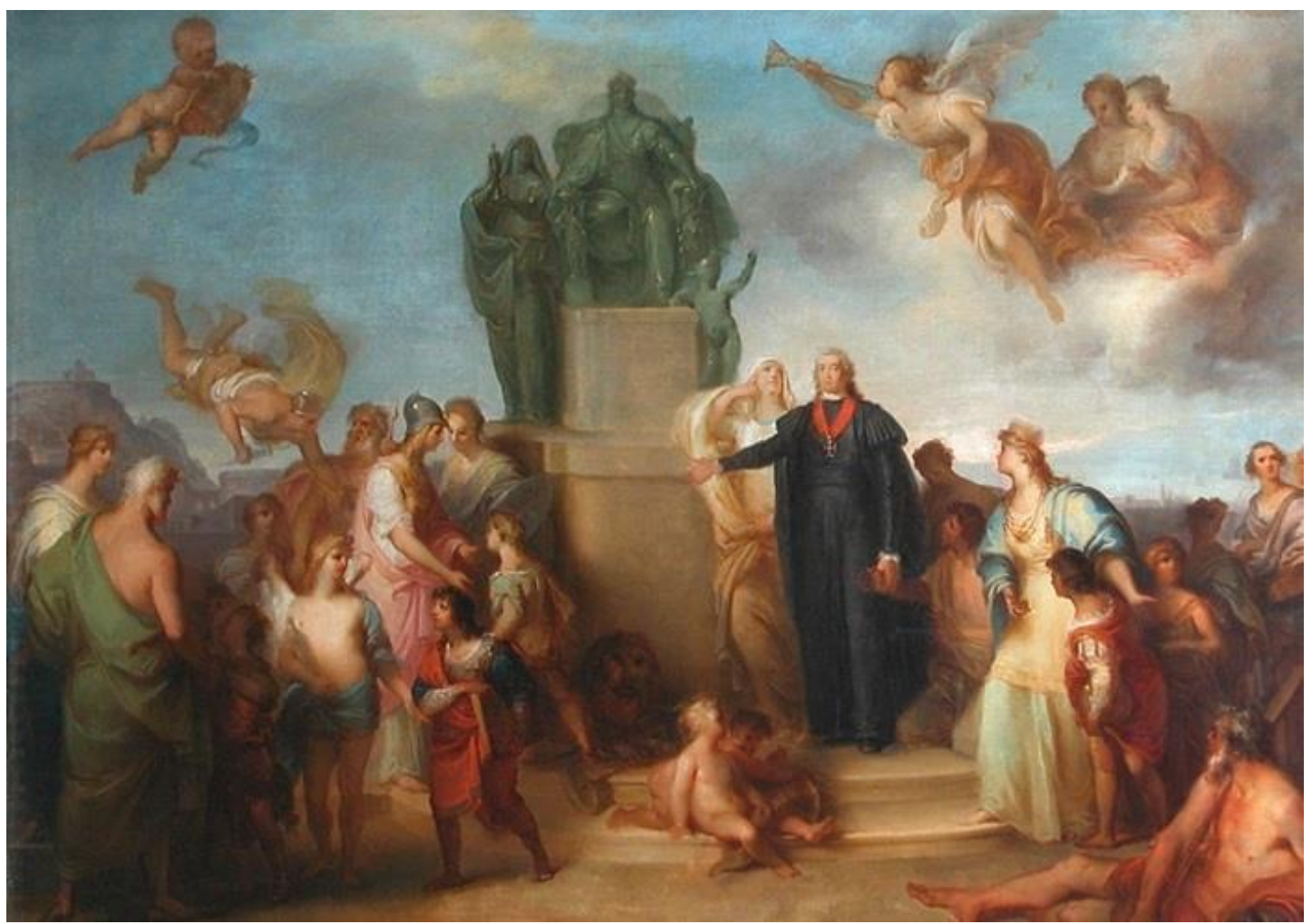

Fonte: Óleo sobre tela (69x95cm) de Domingos António de Sequeira, executado em Roma entre 1792 e 1794, atualmente no Museu do Louvre, em Paris. Ao centro, o retrato do Intendente Geral da Polícia, Diogo Inácio de Pina Manique. Do lado direito, autoretrato de Sequeira, junto ao pintor brasileiro e condiscípulo em Roma, Manuel Dias de Oliveira.

Partirá de Roma em maio de 1795, passando por Bolonha, Parma, Florença, Milão e Veneza, "para obeservar as galerias e monumentos antigos para maior minha instrução" e, segundo as suas próprias palavras, coberto de glória (cf. CARVALHO, 1996, 108).

\section{A cultura artística}

Quem pode chamar-se pintor sem estudar a História, e a Mitologia? Quem pode hoje em dia intentar de ser pintor, sem ler, e meditar as obras de Winkelman, de Mengs, e de tantos outros Santos Padres desta Teologia? (MARTINS, 1942, p.396) 
Neste interrogativo retórico de D. Alexandre, na carta de 8 de junho de 1791 ao Intendente, está talvez a súmula da importância que atribuía à cultura artística, que deveria, necessariamente, secundar o talento natural e a exercitação dos jovens artistas que partiam para Roma. Altamente sintomática a invocação da obra de Johann Joachim Winckelmann, estudioso da arte clássica e um dos expoentes máximos Neoclassicismo, cuja teoria de uma arte harmónica, dotada de uma "nobile semplicità e quieta grandezza" ecoava ainda neste discurso, mais de 20 anos passados sobre a sua morte, e se espelhava nas obras de Canova, David e do próprio Anton Raphael Mengs - que, para além de pintor, fora historiador e crítico de arte, cultor do Antigo e de Rafael, teorizador, no tratado Gedanken über die Schönheit und über den Geschmack in der Malerei (1762), da imitação dos grandes mestres como único instrumento para se obter a beleza ideal, que resultaria da escolha daquilo que na natureza é melhor (cf. ROETTGEN, 2001). A sua coleção de gessos viria a ser adquirida para uso dos estudantes da Academia portuguesa.

O diplomata considerava-se, além disso, ele mesmo um idóneo transmissor dessa cultura artística que preconizava:

(...) todos os domingos os faço fazer Academias na minha presença, dando-lhes eu mesmo os temas, e discorrendo sobre o que fazem conforme o pouco que sei, e apesar disso já se lhes conhece diferença notável depois que principiou este exercício; de sorte que se eu soubera mais, e tivesse mais tempo de livre, pouca necesside teriam do Diretor que aconselho; (MARTINS, 1942, p.396)

Falsa é a modéstia que usa ao considerar "o pouco" que sabe, já que D. Alexandre, se prezava "de ser meio arquiteto" - e tanto lhe bastava para poder interferir na escolha de futuros candidatos à Academia - explanando longamente a própria teoria artística no que a essa arte dizia respeito. Para se ser um grande arquiteto, escreve a 28 de dezembro de 1791 a Pina Manique, seriam necessários

talento, e imaginação além de um grande cabedal de geometria, trignometria, mecânica hidráulica, e outras partes da matemática, que são indispensáveis para formar um arquiteto até da segunda ordem carecendo os da primeira além disto de muitas outras luzes, e estudo independentes em certo modo da ciência propriamente chamada arquitetura como vem a história, e especialmente a história das artes, um 
pouco de filosofia para aguçar e dirigir com segurança o engenho, uma puntura de história natural, e de química para conhecer o modo mais conveniente de usar dos materiais e de corrigir os seus defeitos, suprindo pela arte nesse particular as faltas da natureza mas sobretudo indispensável que tenha uma viveza de fantasia, e de imaginação comparável à de um grande poeta quem quer que aspira a ser um arquiteto comparável a Palladio, Miguel Ângelo, e outros tais. Nestes termos pode V.S. ir lançando as suas linhas para escolher alguns rapazes que mereçam a pena de se dispender com eles a grande soma de dinheiro que é precisa sacrificar para criar arquitetos da $1^{\text {a }}$ ordem; advertindo que como me acho a partir desta Corte para essa, não será desacertado que V.S. suspensa a eleição que houver de fazer de alguns sujeitos para este estudo a fim que eu possa aí palpar as suas disposições visto que me prezo de ser meio arquiteto. (MARTINS, 1942, p.399)

\section{Um diretor para a Academia}

Para o Padre Gregório Pedro Pereira, «ecónomo e vice-Diretor da nova Academia Portuguesa de Belas-Artes que aqui se ressuscitou ultimamente» (AEPSS, liv. VIII. fol. 51 ss.), não se cansou D. Alexandre de procurar um justo benefício ${ }^{48}$, não o considerado todavia à altura de "uma ciência mui vasta", como a pintura ou a escultura, que "é preciso sabê-la, ao menos por teórica para dirigir os outros» ${ }^{49}$. Parecia-lhe, pois, fundamental que a supervisão da Academia fosse assegurada por um erudito e entendedor das belas-artes, que identifica em Giovanni Gherardo De Rossi (1754-1827) ${ }^{50}$ - «uomo di squisito gusto, ed in questa materia di grandi cognizioni fornito", como se lhe refere o Núncio papal Bartolomeo Pacca (PACCA, 1836, 111) - e que, para além de tudo, tinha da cultura artística a inculcar nos rapazes uma visão em tudo semelhante à sua ${ }^{51}$.

\footnotetext{
48 "pelos serviços que está fazendo em vigiar e dirigir, sem alguma sorte de emolumentos, os alunos da Casa Pia do Castelo que o Intendente-Geral da Polícia mandou para esta Corte a aprender as Belas-Artes» desde março de 1791 (AEPSS, liv. VIII. fol. 12 ss.). Obtém finalmente em outubro desse ano a colação dos canonicatos da Colegiada de Guimarães (A.E.P.S.S., liv. VIII. fol. 45 ss.).

${ }^{49}$ Carta de D. Alexandre para Pina Manique de 8 de junho de 1791: «D. Gregório é cheio de zelo, e honra de probidade, e de religião e portanto no que respeita à economia destes rapazes não aconselho a V.S que lhe prefira algum outro; mas D. Gregório não entende nada de pintura, de escultura, nem das outras belas-artes, e quando tivesse alguma luz nessas matérias para falar a uns e a outros, não sabe nem sequer os princípios de que é preciso para dirigir os estudos destes moços a quem é preciso a todo o instante estar sugerindo a um que se aperfeiçoe no desenho, a outro que estude a composição, este que seja mais franco, aquele mais diligente no pincel; a um falta o colorido, a outro a graça, a este a perspectiva, àquele a expressão. "(MARTINS, 1942, 395).

${ }^{50}$ Deste "sommo onore» e também das "speranze di vantaggi futuri» dá conta o próprio De Rossi na carta endereçada ao Cav. di S. Quintino (BRUNETTI, 1846, 188-189).

${ }^{51}$ Escreve Michela Degortes, na linha de Liliana Barroero: «A visão de De Rossi sobre as artes, na sua surpreendente clareza e atualidade, resume os conceitos chave do pensamento coevo nessa matéria; apoiando-se nas ideias de Rafael Mengs (1728-
} 
De Rossi era crítico de arte, dramaturgo e banqueiro e «ao fundar e dirigir o periódico mensal Memorie per le Belle Arti, que publicava os seus ensaios críticos sobre pintura e escultura, a sua voz ganhou cada vez mais peso no debate sobre a arte contemporânea" (DEGORTES, 2016,142). Esta assunção parecia, pois, satisfazer plenamente D. Alexandre, que louva o Diretor em dezembro de 1791, afiançando ao Intendente que podia "confiar completamente no seu zelo, erudição, inteligência e atividade»:

Parece-me que já disse a V.S. que entre as vantagens que resultam à nossa Academia da eleição que fiz do Diretor João de Rossi não é a menor possuir ele uma excelente coleção de painéis de vários e excelentes mestres objeto em que faz algum comércio os quais depositou no quarto que tem na mesma Academia para fazer os seus discursos aos alunos pregando com tanto maior proveito que tem os exemplos à vista entre os quadros, e as estátuas, mas além desta grande vantagem, há outra quase igual na coleção dos livros sobre as belas-artes em geral, e sobre cada uma em particular com as vidas dos artistas mais célebres, além de outros muitos livros de história, mitologia, alegoria, etc., com que compôs uma interessante biblioteca toda sua, e toda destinada para proveito dos alunos que não só bebem excelente instrução naquelas fontes mas adquirem um meio proveitoso para fugir da ociosidade sendo tanto mais interessantes as suas leituras que são acompanhadas com as refleções do Diretor, que já disse ser autor de vários livros de poesia, e belas-artes (...) (MARTINS, 1942, pp.398-399)

É a De Rossi que, já depois da partida de D. Alexandre, em 1794, o Intendente irá ordenar o monumento em honra de D. Maria I, de que o próprio Diretor fará o traço arquitetónico, para além de providenciar aos mármores, esculpidos pelo pensionista João José de Aguiar trabalho concluído no fim do ano de 1797, a tempo de ser confiscado pelos invasores franceses de Roma. Será De Rossi a resgatá-lo por 650 escudos (tinha custado 16 mil) e enviá-lo para Lisboa, antes da segunda enviatura de D. Alexandre ${ }^{52}$.

1779), evidencia-se a primazia do "pintor filósofo", que elabora o próprio estilo a partir da observação, da prática do desenho e do estudo da antiguidade. A relação entre artes figurativas, poesia e filosofia é base imprescindível para a reflexão crítica, e é reconhecida a função didática da arte, em linha com as ideias iluministas de Diderot. No que diz respeito aos cânones de beleza e perfeição, tal como Mengs, De Rossi exalta o glorioso triunvirato de Raffaello, Correggio e Tiziano, e da pintura de Seiscentos, além dos Carracci e de Poussin, aprecia especialmente Guercino e Pietro da Cortona.» (DEGORTES, 2016, 143). 52 «Fechada a Academia e depois de desfeita a República Romana (em 1802), foi pelo Encarregado de Negócios de Portugal mandado encaixotar sob os olhos de João Gerardo de Rossi todo o material que povoara as salas daquela (sic) e, ainda, a estátua de D. Maria I, que de Rossi resgatara aos franceses, por 650 Escudos. Os gessos e os modelos foram enviados para o Castelo de São Jorge, para a Casa Pia, à guarda do pintor José Viale, e integrados na aula de desenho; porém, quando esta fechou para que nos casarões do Castelo se acoitassem as tropas de Junot, os soldados franceses encarregaram-se de tudo 
Mas antes mesmo desta ação notável, já a 14 de setembro de 1793 não lhe poupava elogios Pina Manique, em carta ao Mordomo-mor, Presidente do Real Erário e Ministro do Reino. Depois de citar a ação de D. Alexandre ${ }^{53}$, que tivera "a habilidade de o persuadir (...) de ele ir habitar o palácio em que estão os alunos da Casa Pia de Lisboa, onde se fazem as sessões da mesma Academia" - e onde De Rossi colocara "o seu gabinete de pinturas originais» - pede para o Diretor da Academia o hábito de Cristo e os correspondentes 400 mil reis de tença efetiva (MARTINS, 1942, 391-392) ${ }^{54}$. No seu regresso a Roma, D. Alexandre tenta que De Rossi retome a orientação efetiva de novos alunos de belas-artes que se enviassem para Roma, pensando acrescentar-lhe a função de um agente artístico, que se ocupasse das encomendas e aquisções de obras de arte para Portugal - com o título de "Comissário da Corte Portuguesa", mas nada se concretizou.

\section{Fim da Academia e fim de D. Alexandre}

Dez anos depois de a ter deixado ${ }^{55}$, parte de novo D. Alexandre para Roma, agora como Embaixador Extraordinário pela eleição de Pio VII, chegando a Génova a 18 de maio (A.E.P.S.S., liv. XI, fol. 1 ss.), cidade onde permanecerá até ao nascimento do segundo filho varão, Filipe Maria, a 27 de junho de 1802 (cf. TORRES, 1838, 150) ${ }^{56}$ e escrevendo pela primeira vez da Urbe ao novo Ministro dos Estrangeiros, D. João de Almeida, a 25 de setembro (A.E.P.S.S., liv. XI, fol. $11 \mathrm{ss}$.$) :$

Dispensou-me o Santo Padre (...) de dar entrada pública e ainda semipública, o que foi conveniente ao mesmo Papa, aos Cardeais e à nobreza desta Corte onde ninguém tem galas, nem modo de as ter presentemente para semelhantes funções; porém não foi possível, nem era razão, dispensarem comigo a audiência pública que só é dispendiosa para mim e de prática universal em toda a Europa. Nessa ocasião terei a honra de apresentar a Sua Santidade a carta credencial do Príncipe Regente Nosso

destruir, tendo sido esse o fim inglório do espólio dos grandes artistas romanos - Mengs, Pichler e Battoni - que com tantos cuidados haviam sido reúnidos e enviados para a Corte de Lisboa.» Oliveira Martins confunde as datas das duas remessas: a da estatua e a dos gessos, que será feita por D. Alexandre, como veremos (MARTINS, 1942, 393).

${ }^{53}$ Falando dos progressos dos alunos «que estão na dita Academia Real de Portugal, em Roma, que a sobredita Casa Pia de Lisboa tem ali estabelecido naquela Corte, e vão fazendo os progressos mais admiráveis nas belas-artes, que em poucos anos ficaremos independentes dos Estrangeiros, o que tudo se deve à atividade e amor patriótico do ministro que Sua Magestade ali tem, D. Alexandre de Sousa" (MARTINS, 1942, 391).

${ }^{54}$ Ser-lhe-á concedida a 16 de novembro de 1796 a comenda da Ordem de Santiago de Espada, com pensão perpétua de 200 escudos anuais, a que se lhe acrescentou nova pensão de 200 escudos em 1805, recebida até à morte em 1827 - donde se deduz que continuou a auxiliar os alunos, mesmo depois do fecho da Academia.

${ }_{55}^{5}$ Notícia da chegada no romano Diário Ordinario, $\mathrm{n}^{\circ}$ 181, de 25 de setembro de 1802, p.10. Cf. também CASTRO, 1943,329 ss.

${ }^{56}$ Viúvo de D. Isabel Juliana, D. Alexandre casara a 1 de fevereiriro de 1796 com a sobrinha D. Balbina Cândida de Sousa, filha natural legitimada do seu irmão Filipe, que nascera em Setúbal, a 20 de janeiro de 1775 e morreu em Lisboa, a 2 de maio de 1853. Foi mãe de D. Maria Helena (1797-1867), futura Viscondessa de Beire e D. Filipe Maria (1802-1835), futuro Par do Reino em 1834 e Conselheiro da Fazenda e do Tesouro. 
Senhor de que até agora só dei a cópia ao cardeal Secretário de Estado, conforme é costume, o que foi bastante para ter a satisfação de ir já por três vezes à presença de Sua Santidade em audiência particular. (A.E.P.S.S., liv. XI, fol. 22 v. ss.).

Nos dias seguintes à entrega das credenciais, a 21 de novembro, a imagem que dá de Roma é a de uma cidade abatida material e moralmente (A.E.P.S.S., liv. XI, fol. 24 v. ss.). A invasão e o saque a 10 de fevereiro de 1798 pelas tropas napoleónicas guiadas por Louis-Alexandre Berthier e a proclamação, cinco dias depois, da Repubblica Romana, tinham sido o início de um período de revoltas populares e frustrados contra-ataques, a que se seguiu uma lenta agonia até à retirada dos ocupantes em setembro de 1799.

Neste clima, a Academia portuguesa deixara de ter um funcionamento regular, conquanto o Encarregado de Negócios, Luís Álvares da Cunha e Figueiredo ${ }^{57}$ vá dando ao longo dos anos notícia dos movimentos e da entrega das pensões aos bolseiros de belas-artes e ainda mesmo depois da invasão francesa se refira ao pensionado António Joaquim de Sousa, arquiteto, que partirá em junho de 1800 (A.E.P.S.S., liv. X, fol. 228 v. ss. e idem, idem, fol. 230 ss.). Talvez que a Academia fosse considerada de facto extinta, pois que Pina Manique, em carta ao ao Presidente do Real Erário de 26 de junho de1799, escreve: "o Colégio das Belas Artes, que permaneceu em Roma até ao dia em que os Franceses nela entraram; por cujo motivo os alunos, cujos notáveis progressos são presentes a Sua Magestade e a V.Ex. ${ }^{a}$ passaram para Florença, donde há pouco chegaram a esta capital» (MARTINS, 1942, 393).

Todavia, referindo-se ainda a De Rossi como "Diretor da Academia"58, no ofício que envia ao Ministério a 30 de dezembro de 1802, é evidente que D. Alexandre não a considerava ainda finda, procedendo ao seu desmantelamento apenas em 1803, de que surge uma primeira notícia no ofício de 16 de maio:

Fico também na inteligência de haver de conservar à disposição de José Viale os gessos e modelos que pertenciam à Academia de Portugal, não menos que umas três caixas pertencentes aos alunos; porém devo dizer a V.Ex. ${ }^{a}$ que eu não recebi até agora o Despacho que me acusa escrito em

\footnotetext{
${ }^{57}$ «Durante o longo intervalo das duas Missões ficara a representar-nos Luís Álvares da Cunha e Figueiredo, filho dum Escrivão da Patriarcal, José da Cunha e Figueiredo. (...) Pois este nosso modesto funcionário, de quem hoje ninguém conhecerá o nome, foi o nosso verdadeiro representante junto de Pio VI e nos inícios de Pio VII. Assistiu à devastação de Roma pelos exércitos de Bonaparte, correu os maiores perigos, viveu com as maiores dificuldades económicas, acompanhou Pio VI no seu martírio da Toscana, teve de sair dali quando o Pontífice foi arrastado, moribundo, para França. Teve então de ir para a Sicília, mas entretanto salvou a maior parte dos bens do Estado que ficavam em Roma, escondendoos e confiando-os a pessoas leais e seguros..." (BRAZÃO, 1973 I,19-20).

${ }^{58}$ A respeito da autorização que lhe dá para que na audiência pública uso o hábito de Santiago, que o Regente lhe concedeu (A.E.P.S.S., liv. XI, fol. 29 ss.).
} 
agosto do ano passado sobre este assunto, nem sei quem seja José Viale, nem onde exista. (A.E.P.S.S., liv. XI, fol. 99 v. ss.)

\section{Imagem 8. Morte de D. Alexandre de Sousa e Holstein}
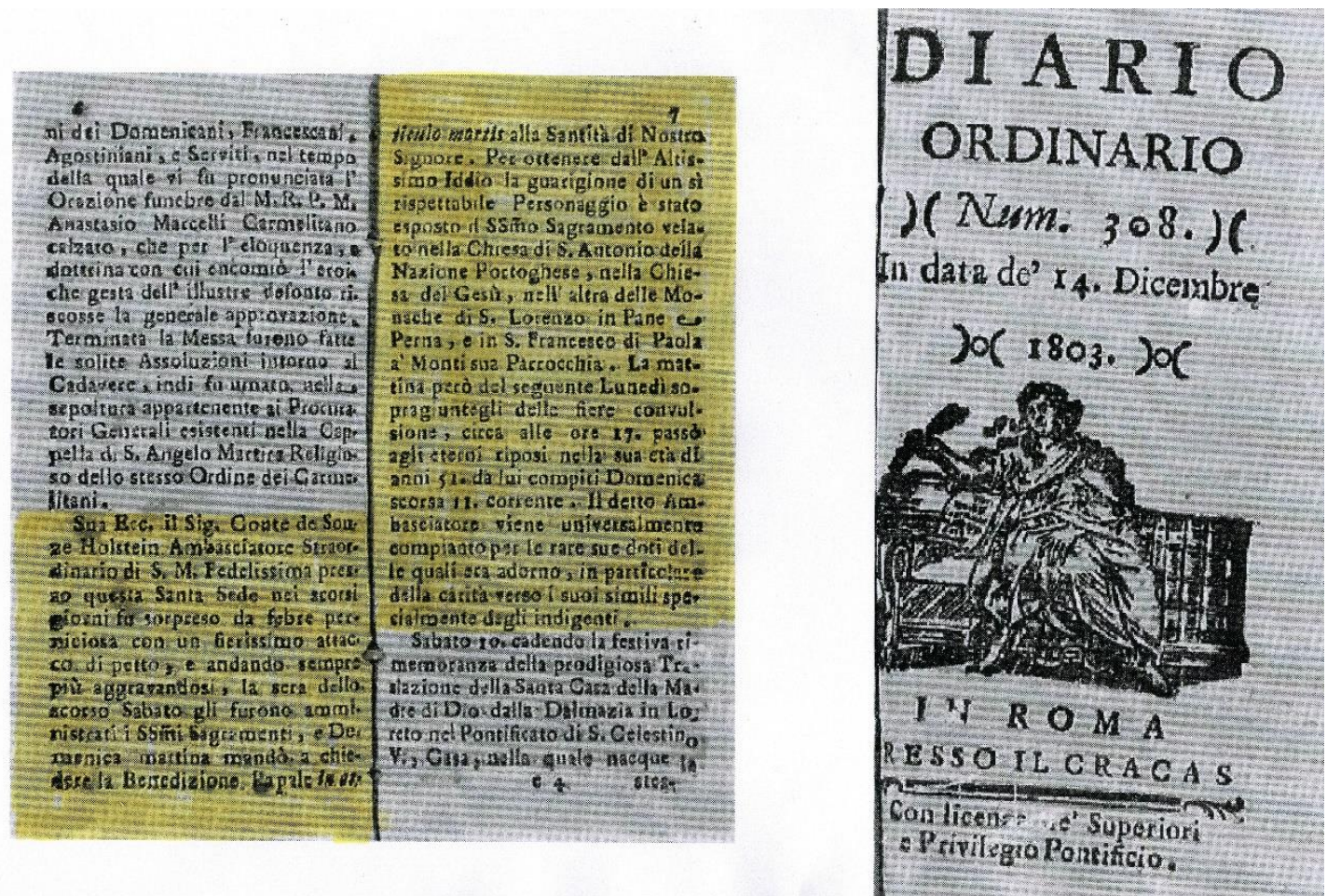

Fonte: Frontispício e páginas do Diario Ordinario de Roma (Cracas) que noticiam o acontecimento - n 308 de 14 de dezembro de 1803, pp.6-7.

De uma nova guerra, que paira já sobre a Europa, chega notícia certa a 16 de junho (A.E.P.S.S., liv. XI, fol. 66 ss.). Mas D. Alexandre não assistirá à invasão de Roma de 2 de fevereiro de 1805, pois sobrevem-lhe a morte a 12 de dezembro de $1803^{59}$, de que dão ampla e circunstanciada notícia os números 308 e 309 do Diário Ordinário: uma fortíssima febre atacara-lhe o peito nos primeiros dias de dezembro ${ }^{60}$, tendo recebido imediatamente os Sacramentos e a bênção papal in articulo mortis; pelo seu restabelecimento tinham sido feitas preces públicas em Santo António dos Portugueses, na igreja próxima de sua casa, San Lorenzo in Panisperna e na sua paróquia, San Francesco di Paola.

${ }^{59}$ A 13 de dezembro de 1803 será D. Pedro de Sousa e Holstein, Conselheiro da Embaixada, a relatar a morte do pai a Luís de Sousa Coutinho, regressado à pasta dos Estrangeiros, já feito Visconde de Balsemão (A.E.P.S.S., liv. XIII, fol. 1).

${ }^{60}$ Notícia presente também em A.E.P.S.S., liv. XI, fol. 63. 
Imagem 9. Caixão de D. Alexandre Na cripta da igreja nacional de Santo António dos Portugueses (geral)

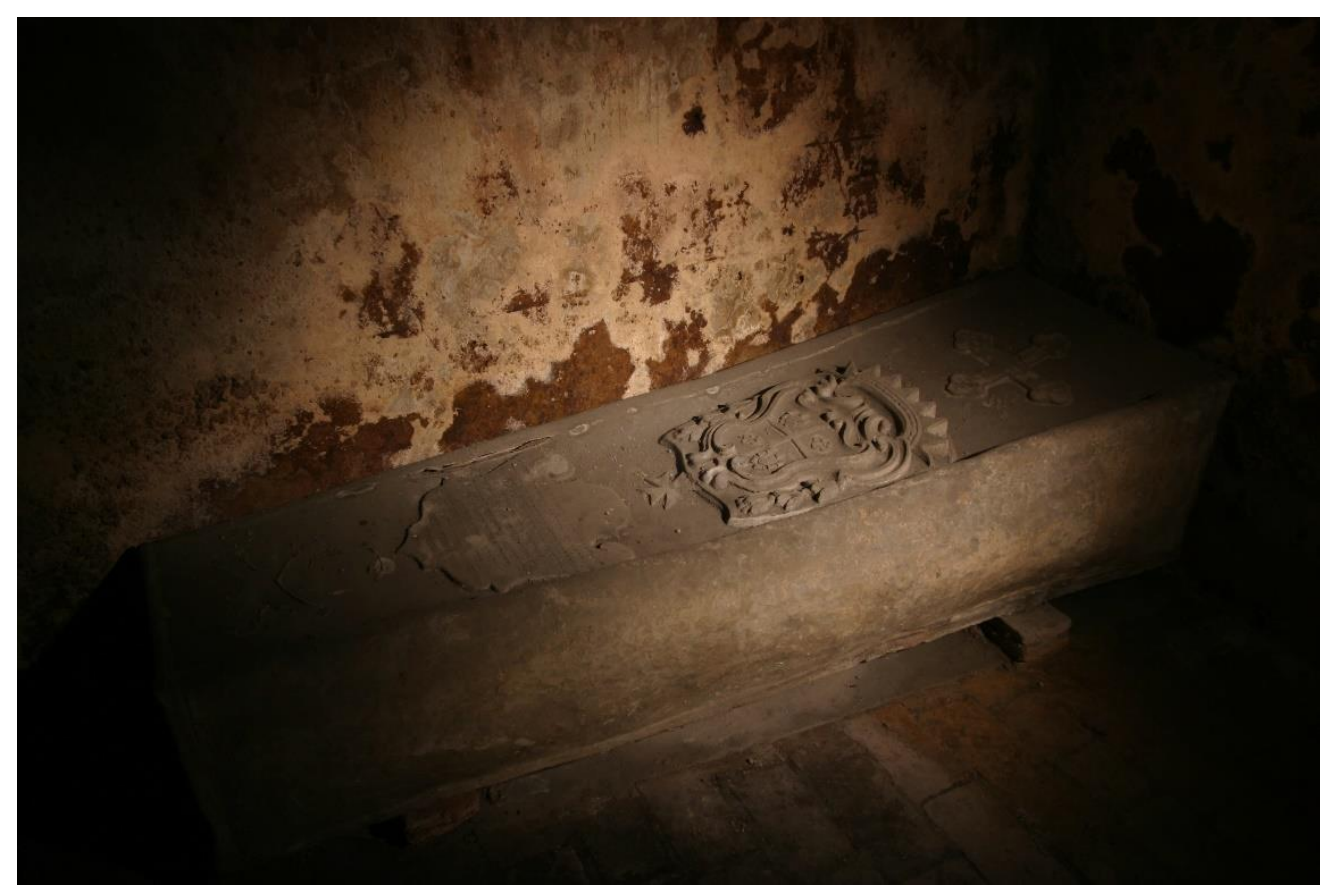

Fonte: Imagem gentilmente cedida pelo Instituto Português de Santo António em Roma. Fotógrafo: Guillermo Luna.

Imagem 9 A. Caixão de D. Alexandre Na cripta da igreja nacional de Santo António dos Portugueses (detalhe)

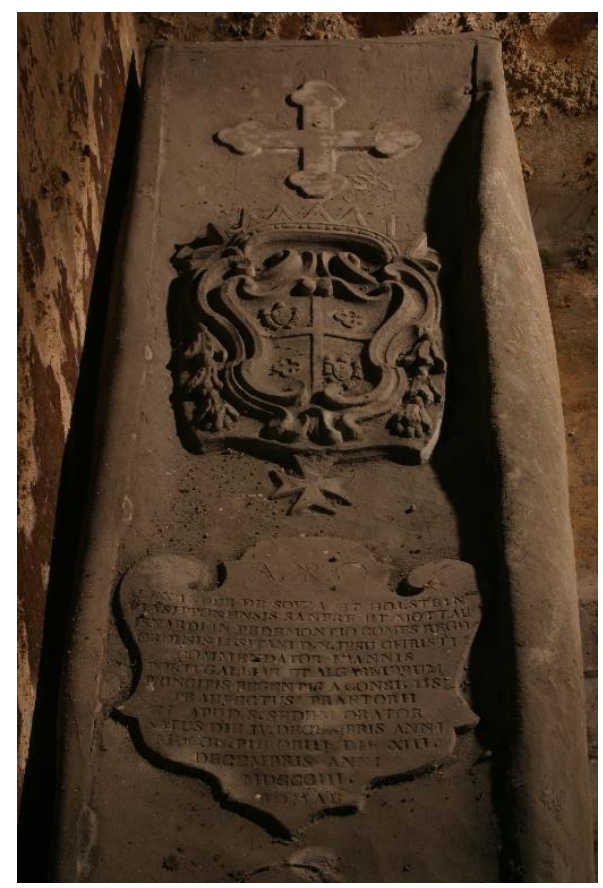

Fonte: Imagem gentilmente cedida pelo Instituto Português de Santo António em Roma. Fotógrafo: Guillermo Luna. 
Exposto o cadáver em câmara ardente, foram montados no palácio da Embaixada três altares declarados privilegiados pelo Papa, onde durante dois dias se rezaram missas continuamente, dali partindo em solene procissão, em quatro carruagens, na véspera do funeral, para a igreja nacional. O rico aparato fúnebre então montado em Santo António dos Portugueses foi o cenário da missa cantada por Mons. Benedetto Fenaja, Arcebispo de Filippi e Vice-gerente de Roma, acompanhado por membros da Capela pontifícia. À cerimónia assistiram Mons. Boni, arcebispo de Nazianzo, Mons. Bertazzoli, arcebispo de Odessa, Mons. Baccolo, bispo de Famagosta e Mons. Menocchio, bispo de Porfiro e sacristão de SS, para além de todo o clero e comunidade portuguesa residentes em Roma. O caixão seria mais tarde transportado para a cripta da igreja nacional, debaixo da capela de Santa Catarina (cf. Diário Ordinário, $\mathrm{n}^{\circ} 308$ de 14 de dezembro de 1803, pp.6-7 e n ${ }^{\circ} 309$ de 17 de dezembro de 1803, pp. 10 14).

Imagem 10. Monumento fúnebre de Alexandre de Sousa e Holstein, por António Canova em 1808, mármore de Carrara $(334 \times 152 \mathrm{~cm})$, capela de Santa Catarina da Igreja de Santo António dos Portugueses em Roma

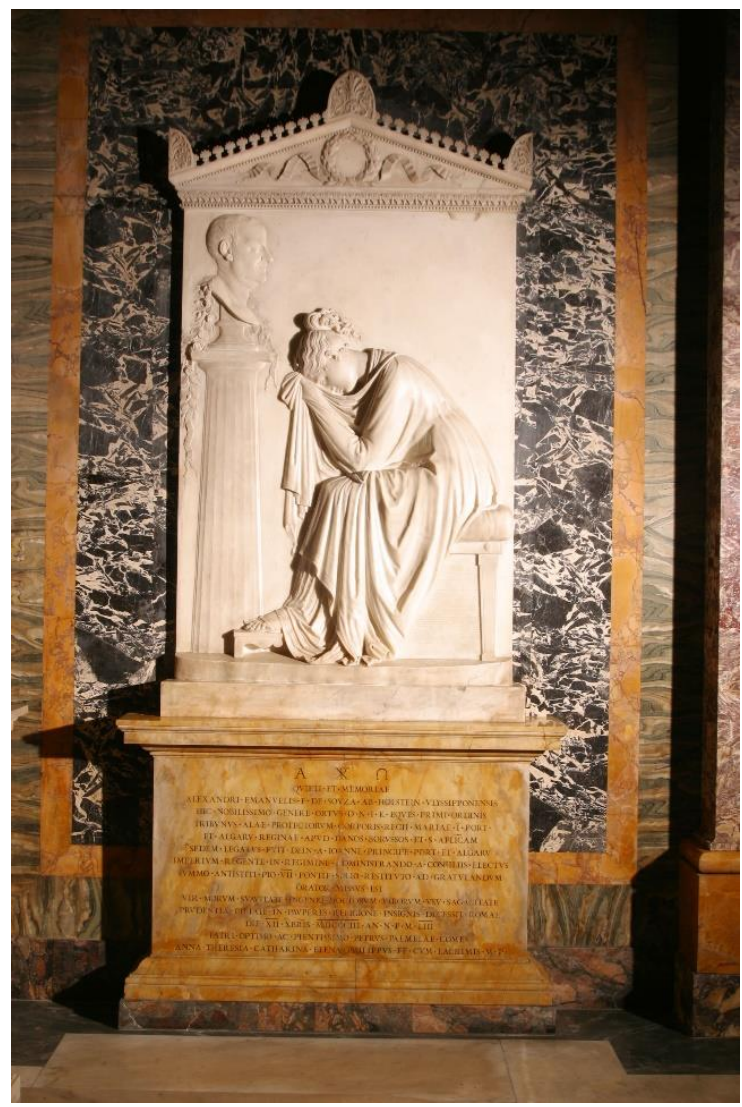

Fonte: Imagem gentilmente cedida pelo Instituto Português de Santo António em Roma. Fotógrafo: Guillermo Luna. 
Canova ergueu-lhe um túmulo na capela (sic) de Santo António dos Portugueses, recebendo em troca do seu trabalho, a estátua grega representando um Sileno, em mármore e tamanho natural que, juntamente com outras antiguidades preciosas foram por D. Alexandre encontradas numa escavação feita ao pé de Roma. (CARVALHO, 1898, p.91) $)^{61}$

\section{Referências}

AFFONSO, Domingos Araujo e VALDEZ, Ruy Dique Travassos. Livro de Oiro da Nobreza,. Braga: Tipografia PAX, 1933.

AUGUSTIN, Kristina, "A trajetória dos castrati nos teatros da corte de Lisboa (séc. XVIII)». Revista Música e Linguagem, Vitória/ES, vol.1, n. 3 (2013), pp.73-94.

ALMEIDA, Fortunato de. História da Igreja em Portugal, v. III. Porto: Livraria Civilização, 1970.

ANDRADE, António Alberto de. Vernei e a cultura do seu tempo. Coimbra: Imprensa da Universidade, 1966.

BARROERO, Liliana, "L'occhio critico di Giovanni Gherardo De Rossi sulle Belle Arti». In AA.VV. Antonio Canova: La cultura figurativa dei grandi centri italiani. Bassano del Grappa: Istituto di ricerca per gli studi su Canova e il Neoclassicismo, 2005, pp.281-295.

BEIRÃO, Caetano. D. Maria I (1777-1792): subsídios para a revisão da história do seu reinado. $3^{\mathrm{a}}$ ed. Lisboa: Empresa Nacional de Publicidade, 1944.

BERNARDY, Amy Allemand. «Instituições e tradições culturais de Portugal em Roma». Estudos Italianos em Portugal, Lisboa, n. 5, (1941), pp.71-76.

BERNARDY, Amy Allemand. Portogallo e Roma. Spoleto: Istituto Nazionale per le Relazioni Culturali con l'Estero, 1941.

BONA, Federico. I da Sousa e i de Silva: presenze portoghesi in ambiente subalpino nel 1700 e 1800. Società Italiana di Studi Araldici. 2014. Disponível em

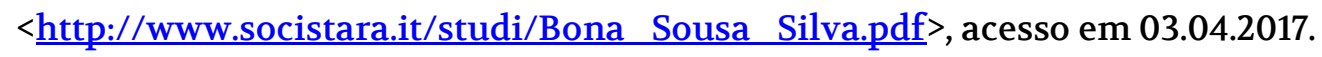

${ }^{61}$ Informação detalhada com referências bibliográficas e documentais sobre o monumento de Canova em ROCCABORGHINI, 1992, 11. 
BOUTRY, Philippe. «Pio VII». In Enciclopedia dei Papi, v. III. Roma: Istituto della Enciclopedia Italiana, 2000, pp.509-529.

BRAZÃO, Eduardo. Relações diplomáticas de Portugal com a Santa Sé: da Revolução Francesa a Bonaparte (1790-1803). Lisboa: Academia Internacional da Cultura Portuguesa, 1973.

BRAZÃO, Eduardo. "Notícia de duas missões a Roma pelo embaixador Dom Alexandre de Sousa e Holstein". In AA.VV. A historiografia portuguesa anterior a Herculano. Lisboa: Academia Portuguesa de História, 1977, pp.382-402.

BRUNETTI, Enrico Castreca (Org.). Lettere inedite di Vincenzo Monti, d'Ippolito Pindemonte, di Luigi Biondi, di Paolo Costa, di Urbano Lampredi, di Tommaso Gargallo, di Gian Gherardo De Rossi e di altri. Roma: Tipografia Gismondi, 1846.

CAFFIERO, Marina. «Pio VI». In Enciclopedia dei Papi, v. III. Roma: Istituto della Enciclopedia Italiana, 2000, pp. 492-509.

CARDOSO, Arnaldo Pinto. A presença portuguesa em Roma. Lisboa: Quetzal Editores, 2001.

CARVALHO, Ayres de. "O Pintor Cirilo Volkmar Machado". In Boletim do Museu Nacional de Arte Antiga, Lisboa, v. III, n. 2 (1956).

CARVALHO, Ayres de. "Os artistas de outrora e as academias de Belas-Artes». In Belas Artes, $\mathbf{n}$. 4, (1982).

CARVALHO, Joaquim Martins Teixeira de. Domingos António de Sequeira em Itália: 1788-95: segundo a correspondencia do Guarda-Joias João António Pinto da Silva. Coimbra: Imprensa de Universidade, 1922.

CARVALHO, José Alberto Seabra. "Uma cronologia». In AA.VV. Sequeira, um Português na Mudança dos Tempos. Lisboa: M.N.A.A., 1996, pp.102-122.

CARVALHO, Maria Amália Vaz de, Vida do Duque de Palmella D. Pedro de Sousa e Holstein, v. I. Lisboa: Imprensa Nacional, 1898.

CASTRO, José de. Portugal em Roma, v. II. Lisboa: União Gráfica, 1939.

CASTRO, José de, O Cardial Nacional. Lisboa: Agência Geral das Colónias, 1943.

CIPRIANI, Angela (Org.). Roma 1771-1819: i giornali di Vincenzo Pacetti. Pozzuoli: Naus, 2011.

COGNASSO, Francesco. "Pio VII». In Enciclopedia Cattolica, v. IX. Vaticano: Ente per l’Enciclopedia Cattolica e per il Libro Cattolico, 1952, pp.1504-1508. 
COSTA, Luís Xavier da. As Belas-Artes plásticas em Portugal durante o século XVIII: resumo histórico. Lisboa: J. Rodrigues, 1934.

COSTA, Luís Xavier da. «Documentos relativos aos alunos que de Portugal foram para o estrangeiro estudar Belas-Artes e Cirurgia, com protecção oficial, nos decénios finais do século XVIII". In Arquivo Histórico de Portugal, v. III. Lisboa: Academia Nacional de Belas-Artes, 1938.

DEGORTES, Michela. «Ensino artístico no estrangeiro: o caso da Academia Portuguesa de Belas-Artes em Roma». In NETO, Maria João e MALTA, Marize (Org.). Coleções de Arte em Portugal e Brasil: As Academias de Belas-Artes: Rio de Janeiro, Lisboa, Porto (1816-1836). Casal de Cambra: Caleidoscópio, 2016, pp.137-148.

FERRÃO, António (Org.). As impressões de um diplomata português na côrte de Berlim: correspondencia oficial de D. Alexandre de Sousa e Holstein, primeiro ministro de Portugal na côrte da Prússia, no tempo de Frederico-Guilherme II (1789-1790). Coimbra: Imprensa da Universidade, 1919.

FERREIRA, A. Aurélio da Costa. Domingos Antonio de Sequeira e a Casa Pia de Lisboa. Coimbra: Typ. Auxiliar d'Escriptorio, 1912.

FRANÇA, José Augusto. A arte em Portugal no século XIX. $3^{\text {a }}$ ed. Venda Nova: Bertrand, 1990.

GENTILE, Luisa Clotilde. «Portugais au-deçà des Alpes: Traces héraldiques d'intérêts dynastiques et familiaux portugais en Piémont et dans la Vallée d'Aoste (XVIe-XIXe siècles)». In Armas e Troféus: revista de história, heráldica, genealogia e arte, IX série, tomo XVI (2014), pp.191-192.

GIUNTELLA, Vittorio E.. «Pio VI». In Enciclopedia Cattolica, v. IX. Vaticano: Ente per l'Enciclopedia Cattolica e per il Libro Cattolico, 1952, pp.1500-1504.

LEFLON, Jean. «La Chiesa Costituzionale». In Storia della Chiesa: La Crisi Rivoluzionaria (17891815), v. XX/1. Torino: S.A.I.E, 1971, pp.85-124.

LUCENA, Armando de. Sequeira na arte do seu tempo. Lisboa: Academia Nacional de Belas Artes, 1969.

MACHADO, Cyrilo Volkmar. Collecção de memórias, relativas às vidas dos pintores, e escultores, architetos, e gravadores portuguezes, e dos estrangeiros, que estiverão em Portugal / recolhidas e ordenadas por Cyrillo Volkmar Machado, pintor ao serviço de S. Magestade o senhor D. João VI. Lisboa: Impr. de Victorino Rodrigues da Silva, 1823. 
MARTINS, Francisco d'Assis Oliveira. "A Academia Portuguesa de Belas Artes em Roma». In Ocidente, Lisboa, vol. 18, (1942).

MARTINS, Francisco d'Assis Oliveira. Pina Manique: o político - o amigo de Lisboa. Lisboa: Soc. Ind. de Tipografia, 1948.

PACCA, Bartolomeo. Notizie sul Portogallo con una breve relazione della Nunziatura di Lisbona dall'anno 1795 fino all'anno 1802. Modena: G. Vincenzi e Comp., 1836.

PAIS, Alexandre Nobre (Org.), Uma família de coleccionadores: poder e cultura, antiga colecção Palmela. Lisboa: Casa-Museu Dr. Anastácio Gonçalves, 2001.

PAMPLONA, Fernando de. Dicionário de Pintores e Escultores Portugueses, v. V. Lisboa: Liv. Civilização Editora, 1988.

PASTOR, Ludovico Barone von. "Pio VI (1755-1799)». In Idem. Storia dei Papi: Storia dei Papi nel periodo dell'Assolutismo: dall'elezione di Benedetto XIV sino alla morte di Pio VI (1740-1799), v. XVI. Roma: Desclée \& C. ${ }^{\text {a }}$ Editori Pontifici, 1955, pp. 460-497.

PEREIRA, Paulo (Org.), História da Arte em Portugal, v. III. Lisboa: Círculo de Leitores, 1995.

RACZYNSKI, Atanazy. Les Arts en Portugal: lettres adressées a la société artistique et scientifique de Berlin et accompagnées de documents. Paris: Jules Renouard, 1846.

RIO MAIOR, Marquês de. O Marquês de Pombal e os Sousas do Calhariz: inéditos pombalinos. Lisboa: Tip. Inglesa, 1936.

ROCCA, Sandra Vasco e BORGHINI, Gabriele (Org.). Santo Antonio dei Portoghesi. Roma: Istituto Centrale per il Catalogo e la Documentazione - Árgos, 1992.

ROETTGEN, Steffi (Org.). Mengs: la scoperta del Neoclassico. Venezia: Marsilio, 2001.

SAMPAYO, Luiz Teixeira de. Em volta do processo dos Távoras: documentos do arquivo do Ministério dos Negócios Estrangeiros. Coimbra: Imp. da Universidade, 1929.

SERRÃO, Joaquim Veríssimo. História de Portugal: O Despotismo Iluminado (1750-1807), v.VI. Lisboa: Verbo, 1982.

SERRÃO, Joel (Org.). Dicionário de História de Portugal, v. VI. Porto: Figueirinhas, 1981.

SOARES, Ernesto. Livro da matrícula dos discípulos ordinários e extraordinários da aula pública de desenho, a qual principiou a ter exercício no $1^{\circ}$ de Dezembro do ano de 1781. Lisboa: Tip. Henrique Torres, 1935. 
TABORDA, José da Cunha. Regras da arte da pintura: com breves reflexões criticas sobre os caracteres distinctivos de suas escolas: vidas e quadros dos seus mais célebres professores: escritas na lingua italiana por Micael Angelo Prunetti dedicadas as excellentissimo senhor Marquez e Borba. Lisboa: Impr. Regia, 1815.

TORRES, João Carlos Feio Cardoso de Castelo Branco e. Resenha das famílias titulares do reino de Portugal: acompanhada das noticias biographicas de alguns individuos das mesmas familias. Lisboa: Imprensa Nacional, 1838.

VALENTE, Vasco. «Correspondência inédita de Pina Manique». In Museu, Lisboa, n. 15-16 (1950), pp.33-34.

ZUQUETE, Afonso Eduardo Martins Zuquete (Org.). Nobreza de Portugal e do Brasil, v.III. Lisboa: Editorial Enciclopédia, 1960.

Recebido em: 12-06-2017

Aceito em: 11-07-2017 